\title{
Choosing the Right Life Partner: Ecological Drivers of Lichen Symbiosis
}

OPEN ACCESS

Edited by:

Lucia Muggia,

University of Trieste, Italy

Reviewed by:

Rebecca Yahr

Royal Botanic Garden Edinburgh,

United Kingdom

George Newcombe,

University of Idaho, United States

Raquel Pino-Bodas,

Universidad Compluse de Madrid,

Spain

*Correspondence:

Lucie Vančurová

Iucie.vancurova@natur.cuni.cz

Specialty section:

This article was submitted to

Microbe and Virus Interactions with

Plants,

a section of the journal

Frontiers in Microbiology

Received: 14 September 2021 Accepted: 10 November 2021

Published: 14 December 2021

Citation:

Vančurová L, Malí̌ek J, Steinová J and Škaloud P (2021) Choosing the Right Life Partner:

Ecological Drivers of Lichen

Symbiosis.

Front. Microbiol. 12:769304

doi: 10.3389/fmicb.2021.769304

\author{
Lucie Vančurová $^{1 *}$, Jiři Malíček ${ }^{2}$, Jana Steinová ${ }^{1}$ and Pavel Škaloud ${ }^{1}$ \\ 'Department of Botany, Faculty of Science, Charles University, Prague, Czechia, ${ }^{2}$ Institute of Botany, The Czech Academy of \\ Sciences, Prưhonice, Czechia
}

Lichens are an iconic example of symbiotic systems whose ecology is shaped by the requirements of the symbionts. Previous studies suggest that fungal (mycobionts) as well as photosynthesizing (phycobionts or cyanobionts) partners have a specific range of acceptable symbionts that can be chosen according to specific environmental conditions. This study aimed to investigate the effects of climatic conditions and mycobiont identity on phycobiont distribution within the lichen genera Stereocaulon, Cladonia, and Lepraria. The study area comprised the Canary Islands, Madeira, Sicily, and the Aeolian Islands, spanning a wide range of climatic conditions. These islands are known for their unique and diverse fauna and flora; however, lichen phycobionts have remained unstudied in most of these areas. In total, we genetically analyzed 339 lichen samples. The phycobiont pool differed significantly from that outside the studied area. Asterochloris mediterranea was identified as the most abundant phycobiont. However, its distribution was limited by climatic constraints. Other species of Asterochloris and representatives of the genera Chloroidium, Vulcanochloris, and Myrmecia were also recovered as phycobionts. The selection of symbiotic partners from the local phycobiont pool was driven by mycobiont specificity (i.e., the taxonomic range of acceptable partners) and the environmental conditions, mainly temperature. Interestingly, the dominant fungal species responded differently in their selection of algal symbionts along the environmental gradients. Cladonia rangiformis associated with its phycobiont $A$. mediterranea in a broader range of temperatures than Stereocaulon azoreum, which favors other Asterochloris species along most of the temperature gradient. Stereocaulon vesuvianum associated with Chloroidium spp., which also differed in their temperature optima. Finally, we described Stereocaulon canariense as a new endemic species ecologically distinct from the other Stereocaulon species on the Canary Islands.

Keywords: Asterochloris mediterranea, lichen, Macaronesia, phycobiont sharing, specificity, Stereocaulon canariense, symbiosis, temperature gradient

\section{INTRODUCTION}

The Canary Islands, Madeira, Sicily, and the Aeolian Islands are known for their unique and diverse fauna and flora (Troia, 2012; Di Gristina et al., 2016; Giovino et al., 2016; del Arco Aguilar and Rodríguez Delgado, 2018). Macaronesia is also known for its many endemic lichens (Sérusiaux et al., 2011; Sparrius et al., 2017; Vondrák et al., 2020), and numerous 
lichen taxa from this area have been described (Crespo et al., 2006; Hafellner, 2008; Hernández Padrón and Pérez-Vargas, 2010; van den Boom and Ertz, 2013; van den Boom and Clerc, 2015; van den Boom and Magain, 2020; Vondrák et al., 2020). A substantial elevation gradient is typical in most of these areas; therefore, the climatic conditions are diverse despite the relatively small area of the islands. The vegetation is clearly divided into altitudinal belts. These belts are asymmetrically developed on the windward (cooler, more humid and rainier, and more climatically diverse) and leeward (warmer and drier) slopes (del Arco Aguilar and Rodríguez Delgado, 2018). All these islands, except for Sicily, are of volcanic origin.

Lichens are a classic example of symbiotic systems growing worldwide from polar to tropical regions. Due to their symbiotic nature, they can cope well with harsh conditions and newly formed bare substrates. The genera Cladonia, Lepraria, and Stereocaulon belong to the two closely related families Cladoniaceae (Cladonia) and Stereocaulaceae (Stereocaulon and Lepraria; Lücking, 2019). These mycobionts are known to preferably associate with Asterochloris phycobionts (Piercey-Normore and DePriest, 2001; Yahr et al., 2004; Nelsen and Gargas, 2006, 2008; Beiggi and Piercey-Normore, 2007; Bačkor et al., 2010; Škaloud and Peksa, 2010; Peksa and Škaloud, 2011). When describing the relationships between phycobionts and mycobionts, the terms specificity and selectivity are frequently used. The specificity delimits the taxonomic range of acceptable partners, whereas selectivity refers to the preference for a particular group of partners (Rambold et al., 1998; Yahr et al., 2004, 2006). Particular species of Cladonia, Lepraria, and Stereocaulon differ in their preferred Asterochloris species-level lineages (i.e., they are selective towards their phycobionts; Peksa and Škaloud, 2011; Škaloud et al., 2015; Steinová et al., 2019; Vančurová et al., 2020). A relatively high number of studies have focused on phycobionts of Cladonia, Lepraria, and Stereocaulon; however, new phycobiont species-level lineages continue being discovered (Moya et al., 2015; Vančurová et al., 2018; Pino-Bodas and Stenroos, 2020; Kosecka et al., 2021). In addition, other trebouxiophycean algal genera have been detected as phycobionts of Stereocaulon (Beck, 2002; Vančurová et al., 2015, 2018, 2020; Kosecka et al., 2021), Cladonia (Ahmadjian and Jacobs, 1981; Korchikov et al., 2018; Osyczka et al., 2020), and Lepraria (Engelen et al., 2010). The ability to associate with an alternative photobiont (i.e., lower selectivity) can be caused by a stressful environment, as previously shown (Romeike et al., 2002; Engelen et al., 2010; Osyczka et al., 2020).

Since lichen phycobionts in this region have remained almost unresearched (past studies involved only a limited number of samples; Muggia et al., 2014; Leavitt et al., 2015; Moya et al., 2015, 2018; Boluda et al., 2019; Molins et al., 2020), our aim was to supplement the missing information on photobiont diversity in this study area and explore ecological factors shaping symbiotic relationships. Moreover, several studies have documented the phycobionts that are shared by diverse lichen species/genera (Bačkor et al., 2010; Vargas Castillo and Beck, 2012; Peksa et al., in preparation), whereas other studies failed to search for the source of lichen phycobionts (Vančurová et al., 2020). Therefore, we also examined the sharing of phycobionts within the lichen community. This is closely related to the level of specificity and selectivity of the symbiotic partners. Hence, the main questions we addressed were what are (1) the patterns of phycobiont diversity within the study area, (2) the shared pool of phycobionts, and (3) the effect of the climatic conditions on the symbiotic relationships.

\section{MATERIALS AND METHODS}

\section{Taxon Sampling}

We analyzed a total of 339 specimens (Supplementary Table 1) belonging to three closely related fungal genera Cladonia $(n=179)$, Lepraria $(n=23)$, and Stereocaulon $(n=137)$ collected between years 2011 and 2020 on the Canary Islands (El Hierro, La Palma, La Gomera, Tenerife, Gran Canaria, Lanzarote), Madeira, Sicily, and the Aeolian Islands (Vulcano, Salina, Stromboli; Supplementary Figure 1). The sampling sites represented diverse habitats from malpaíses (i.e., barren landscapes) to a laurel forest, various types of substrates, and were located at a range of altitudes $75-2,360 \mathrm{~m}$. We identified the mycobiont morphospecies using standard morphological methods, taxonomical keys (e.g., Lamb, 1978; Baruffo et al., 2006; Burgaz and Ahti, 2009) and thin-layer chromatography (TLC) on Merck silica gel 60 F254 pre-coated glass plates in solvent systems A, B, and C, according to Orange et al. (2001). For the purpose of describing Stereocaulon species, measurements and observations were done in water, except for ascospores and paraphyses observed in $\mathrm{KOH}$. Lichen specimens were deposited in the Herbarium of the Institute of Botany, the Czech Academy of Sciences (PRA), and the private herbarium of J. Malíček.

\section{DNA Extraction, Amplification, and Sequencing}

We extracted DNA directly from lichen thalli (total lichen DNA) following the standard CTAB protocol for lichens (Cubero et al., 1999). Firstly, we examined thalli under a dissecting microscope and washed them with running water (except for Lepraria thalli) before DNA extraction to prevent contamination by soredia from other lichens. We amplified the algal and fungal nuclear internal transcribed spacer (ITS, ITS1-5.8S-ITS2 rDNA) and the algal actin type I gene (including one complete exon and two introns located at codon positions 206 and 248; Weber and Kabsch, 1994) using primers listed in Table 1. The PCR conditions were as described in Vančurová et al. (2018). Every PCR run included negative controls, without a DNA template. The PCR products were purified using by NucleoMag ${ }^{\circledR}$ NGS Clean-up and Size Select kit (MachereyNagel, Duren, Germany) and sequenced using the same primers at Macrogen in Amsterdam, Netherlands. The 507 newly obtained sequences of the ITS rDNA and actin type I regions are available in GenBank under accession numbers OL622077-OL622095 and OL625120-OL625607 (Supplementary Table 1).

\section{Sequence Alignment and DNA Analyses}

We prepared individual sequence alignments for Stereocaulon, Cladonia, Lepraria, Chloroidium, Vulcanochloris (ITS rDNA), 
TABLE 1 | Primers used in this study.

\begin{tabular}{|c|c|c|c|}
\hline Name & Sequence & Function & References \\
\hline nr-SSU-1780-5' & 5'-CTG CGG AAG GAT CAT TGA TTC-3' & Algal ITS region, algal-specific & Piercey-Normore and DePriest, 2001 \\
\hline ITS1-F-5' & 5'-CTT GGT CAT TTA GAG GAA GTA A-3' & Fungal ITS region, fungal-specific & Gardes and Bruns, 1993 \\
\hline ITS4-3' & 5'-TCC TCC GCT TAT TGA TAT GC-3' & Algal and fungal ITS region, universal & White et al., 1990 \\
\hline a-nu-act1-0645-5' & 5'-GAC AGA GCG TGG KTA CAG-3' & Actin type I locus, algal specific & Nelsen and Gargas, 2006 \\
\hline a-nu-act1-0818-3' & 5'-TGA ACA GCA CCT CAG GGC A-3' & Actin type I locus, algal specific & Nelsen and Gargas, 2006 \\
\hline ActinF2 Astero-5' & 5'-AGC GCG GGT ACA GCT TCA C-3' & Actin type I locus, algal specific & Škaloud and Peksa, 2010 \\
\hline ActinR2 Astero-3' & 5'-CAG CAC TTC AGG GCA GCG GAA-3' & Actin type I locus, algal specific & Škaloud and Peksa, 2010 \\
\hline ActinF Astero-5' & 5'-GGG TAC AGC TTC AC-3' & Actin type I locus, algal specific & Vancurová et al., 2018 \\
\hline ActinR Astero-3' & 5'-TGA ACA GCA CTT CAG GGC A-3' & Actin type I locus, algal specific & Vancurová et al., 2018 \\
\hline ActinF3 Astero-5' & 5'-AGC TTC ACC ACC ACT GCA G-3' & Actin type I locus, algal specific & Vancurová et al., 2018 \\
\hline ActinR3 Astero-3' & 5'-AGC GGA AKC GCT CGC TGC C-3' & Actin type I locus, algal specific & Vancurová et al., 2018 \\
\hline
\end{tabular}

and Asterochloris (ITS rDNA and actin type I) datasets using MAFFT v.7 software (Katoh and Standley, 2013). The sequences obtained for Asterochloris were analyzed as a single locus dataset for the ITS rDNA (data not shown) and as a concatenated dataset of ITS rDNA and actin type I loci. In the case of Cladonia, we used Gblocks to remove introns from alignment and to eliminate poorly aligned positions (Castresana, 2000).

Supplementary Table 2 summarizes a total number of sequences included in particular alignments, newly obtained sequences, previously published sequences originated from the study area, reference sequences retrieved from GenBank, and unique sequences after deleting identical ones. All DNA alignments are freely available on Mendeley Data: http://dx.doi. org/10.17632/428v52svtp.1.

Phylogenetic trees were inferred with Bayesian Inference (BI) using MrBayes v.3.2.7a (Ronquist and Huelsenbeck, 2003; Ronquist et al., 2012), maximum likelihood (ML) analysis using GARLI v.2.0 (Zwickl, 2006), and maximum parsimony (MP) analysis using PAUP v.4.0b10 (Swofford, 2003). BI and ML analyses were carried out on a partitioned dataset to differentiate among ITS1, $5.8 \mathrm{~S}$ and ITS2 rDNA, actin intron 206, actin intron 248, and actin exon regions. Substitution models (Supplementary Table 3) were selected using the Bayesian information criterion (BIC) as implemented in JModelTest2 (Guindon and Gascuel, 2003; Darriba et al., 2012). Two parallel MCMC runs, with four chains, were carried out for 10 and 5 million generations for Asterochloris and other datasets, respectively. Trees and parameters were sampled every 100 generations. Convergence of the two cold chains was assessed during the run by calculating the average $\mathrm{SD}$ of split frequencies (SDSF). The SDSF value between simultaneous runs was < 0.01 in all cases. Finally, the burn-in values were determined using the "sump" command. ML analysis was carried out using default settings, five search replicates, and the automatic termination set at 5 million generations. The MP analysis was performed using heuristic searches with 1,000 random sequence addition replicates and random addition of sequences (the number was limited to $10^{4}$ per replicate). ML and MP bootstrap support values were obtained from 100 to 1,000 bootstrap replicates, respectively. Only one search replicate was applied for ML bootstrapping.
We maintained the nomenclature and species boundaries delimited in recent studies (Škaloud et al., 2015; Vančurová et al., 2018, 2020; Kosecka et al., 2021) for Asterochloris species and the species boundaries delimited by Vančurová et al. (2018) and the nomenclature used therein (OTU1-OTU57) for Stereocaulon species-level lineages.

\section{Interaction Networks}

We depicted the interactions between phycobiont species-level lineages in the genus Asterochloris and mycobiont genera and between phycobiont species-level lineages and mycobiont specieslevel lineages in the genus Stereocaulon as interaction networks produced using bipartite package (Dormann et al., 2008) in R.

\section{Niche Hypervolumes}

The climatic niche of the most abundant species-level lineages of phycobionts and Stereocaulon mycobionts were represented using the Hutchinsonian niche concept that describes a species niche as an $\mathrm{n}$-dimensional hypervolume, where the dimensions are environmental variables (Hutchinson, 1957). In the present study, these environmental dimensions were defined based on 19 Bioclim variables (Karger et al., 2017). We constructed the climatic hypervolumes by multivariate kernel density estimation (Blonder et al., 2014). First, we performed the PCA analysis of 19 Bioclim variables to reduce the total number of predictors. The first two PCA axes (explaining $82 \%$ of the total variance) were then selected to calculate hypervolumes for each specieslevel lineage and genus. The boundaries of the kernel density estimates were delineated by the probability threshold, using the 0.85 quantile value. To project the niche spaces of particular lineages, hypervolume contours were plotted based on 5,000 random background points, using the alphahull contour type and alpha smoothing value 0.55 . The analyses were performed in R, using the hypervolume (Blonder et al., 2014) and alphahull (Pateiro-Lopez and Rodriguez-Casal, 2016) packages.

\section{Statistical Comparisons of Contrasting Phycobiont Groups}

To assess the influence of climatic variables on phycobiont distribution, the contrasting phycobiont groups were compared for each Bioclim variable and altitude using Welch's two-sample 


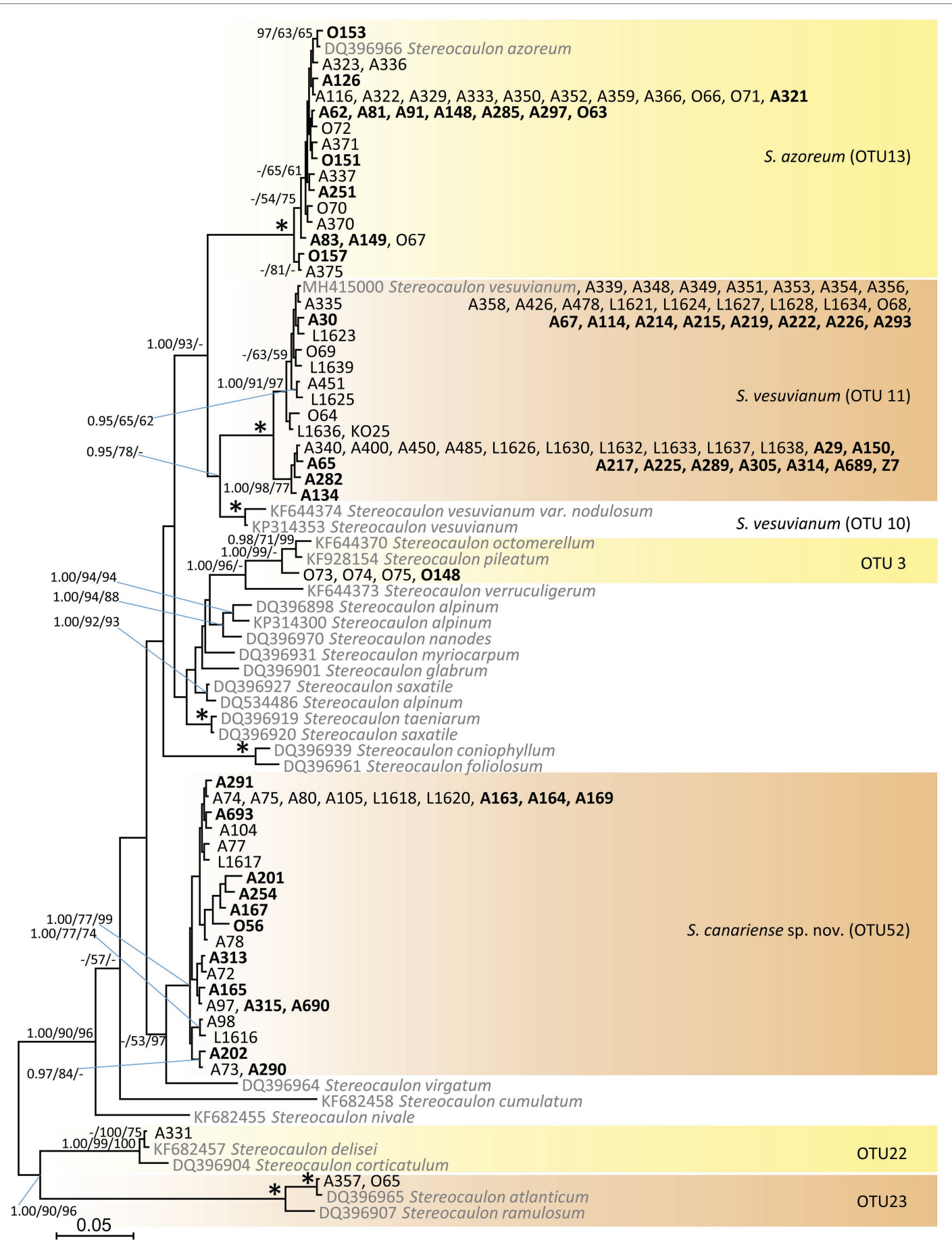

FIGURE 1 | Phylogenetic hypothesis (unrooted tree) of Stereocaulon resulting from Bayesian analysis of ITS rDNA. Values at the nodes indicate the statistical supports of Bayesian posterior probability (left), maximum-likelihood bootstrap (middle) and maximum parsimony bootstrap (right). Fully supported branches $(1.0 / 100 / 100)$ are marked with an asterisk. Scale bar shows the estimated number of substitutions per site. Newly obtained sequences are marked in bold. We selected the reference sequences from GenBank (in grey) taking care to cover eight main Stereocaulon clades (Högnabba, 2006).

t-test. We compared: (1) Asterochloris mediterranea (as the most abundant phycobiont in the study area) with other Asterochloris spp. in association with all mycobionts, (2) A. mediterranea with other Asterochloris spp. in association with Cladonia rangiformis (as the most abundant Cladonia species in the study area) mycobiont, (3) A. mediterranea with other Asterochloris spp. in association with Stereocaulon azoreum mycobiont (as the most abundant Stereocaulon species 
in the study area associated with Asterochloris spp.), and (4) Chloroidium ellipsoideum with C. lichenum A (sensu Darienko et al., 2018) in association with Stereocaulon vesuvianum (OTU11) mycobiont (as the most abundant Stereocaulon species in the study area). We tested phycobionts in pairs with their mycobionts to inspect ecological requirements of the symbiotic system (unlike to separate analyses of symbiotic partners in previous studies, e.g., Vančurová et al., 2018). We could not compare those groups of phycobionts associated with Lepraria spp. mycobionts due to the low number of samples. We performed the analyses in $\mathrm{R}$ using function t.test.

\section{RESULTS}

\section{Diversity of Mycobionts}

We recovered Stereocaulon mycobionts from the study area in six lineages (Figure 1): OTU13 (identified morphologically as S. azoreum and clustered with $S$. azoreum sequences), OTU11 (identified morphologically as $S$. vesuvianum), OTU3 (identified morphologically as $S$. pileatum and clustered with $S$. pileatum and S. octomerellum), OTU52 (described here as a new species Stereocaulon canariense; sister to $S$. virgatum sequence DQ396964), OTU22 (clustered with S. delisei and S. corticatulum), and OTU23 (clustered with S. atlanticum and S. ramulosum). The most frequent species in the study area was $S$. vesuvianum (47\% of the Stereocaulon samples).

A Bayesian analysis of the ITS rDNA of Cladonia mycobionts resulted in 22 supported Cladonia lineages (Supplementary Figure 2). The most recovered Cladonia species was C. rangiformis (30\% of the Cladonia samples), followed by C. humilis (20\% of the Cladonia samples). In most cases, phylogenetically separated lineages corresponded to morphologically delimited species; however, the lineage "Cladonia sp. 1" contained several morphologically different entities. It has been previously reported that ITS rDNA may fail to distinguish Cladonia species in some cases (Kelly et al., 2011; Kanz et al., 2015); however, it has been suggested as a Cladonia barcode marker at the same time (Pino-Bodas et al., 2013).

The phylogenetic hypothesis resulting from the Bayesian analysis of the ITS rDNA sequences of Lepraria (Supplementary Figure 3) was congruent with that of previous studies (Crespo et al., 2006; Tretiach et al., 2009). We recovered Lepraria mycobionts from the study area in five lineages. The most abundant was L. santosii (55\% of Lepraria samples), originally described from Tenerife (Crespo et al., 2006).

\section{Diversity of Phycobionts}

A phylogram resulting from the Bayesian analysis of ITS rDNA and actin type I sequences of Asterochloris is shown in Figure 2. We recorded phycobionts from the study area in eight species-level lineages. The overwhelming majority of samples belonged to A. mediterranea (72\% of Asterochloris samples). A. woessiae and A. italiana were also relatively common (16 and 7\%, respectively). Other lineages were rather rare. The lineage StA10 is a new, highly resolved lineage in Asterochloris.

The phylogenetic hypothesis resulting from the Bayesian analysis of the ITS rDNA sequences of Chloroidium (Figure 3) was congruent with that of previous studies (Darienko et al., 2018; Vančurová et al., 2018). Since C. lichenum became a paraphyletic species (divided into three clades: A, B, and C) after the last taxonomic revision (Darienko et al., 2018), we considered the two monophyletic clades C. lichenum A and $C$. lichenum B as species level-lineages (following species delimitation analyses; Vančurová et al., 2018). We recovered Chloroidium phycobionts from the study area in three specieslevel lineages: C. ellipsoideum (45\% of Chloroidium samples), C. lichenum A (50\% of Chloroidium samples), and C. lichenum B.

Furthermore, we recovered Vulcanochloris phycobionts from the study area in three lineages corresponding to three species (Figure 4): V. symbiotica (70\% of Vulcanochloris samples), $V$. guanchorum, and $V$. canariensis.

Finally, we confirmed the identity of sample A194 by a BLAST search against the GenBank database. The most similar hit (95\% sequence identity) was Myrmecia israliensis KY981668. Therefore, we labelled this sample as Myrmecia sp.

\section{Distribution of Phycobionts}

In total, we found 15 species-level lineages within four genera of phycobionts, from one to nine on each island (Figure 5). Madeira was identified as the most phycobiont species-rich island in our study area. The number of species-level lineages was highest (4.1) also after rarefaction to seven samples, which was the smallest number of samples per island in the dataset.

Asterochloris mediterranea represented the most abundant phycobiont in our dataset, was present on all studied islands and formed associations with all three mycobiont genera (Figures 5, 6A). However, its prevalence in the thalli of different genera of mycobionts varied. Asterochloris mediterranea was present in 83,73 , and $28 \%$ of the thalli involving Asterochloris phycobionts in association with Cladonia, Lepraria, and Stereocaulon, respectively (Figure 6B). Asterochloris woessiae and Asterochloris StA10 were also shared by all three mycobiont genera and present on multiple islands. On the other hand, A. italiana and A. glomerata associated solely with representatives of Stereocaulon and Cladonia.

Chloroidium ellipsoideum associated with S. vesuvianum and Stereocaulon OTU23 (Figures 5, 6B), was the second most geographically widespread phycobiont, and was present on eight islands (absent on Gran Canaria, Lanzarote, and Isola Salina).

The phycobionts Myrmecia sp. (associated with a Cladonia mycobiont), Asterochloris clade A11 (with Cladonia), and A. stereocaulonicola (with Stereocaulon) were recorded only once in our dataset. The phycobiont $A$. aff. italiana was found in three samples but only on a single island (Madeira) and was associated with a single mycobiont (Stereocaulon azoreum).

Vulcanochloris phycobionts were restricted to the Canary Islands, namely La Palma, Lanzarote, El Hierro, and Gran 


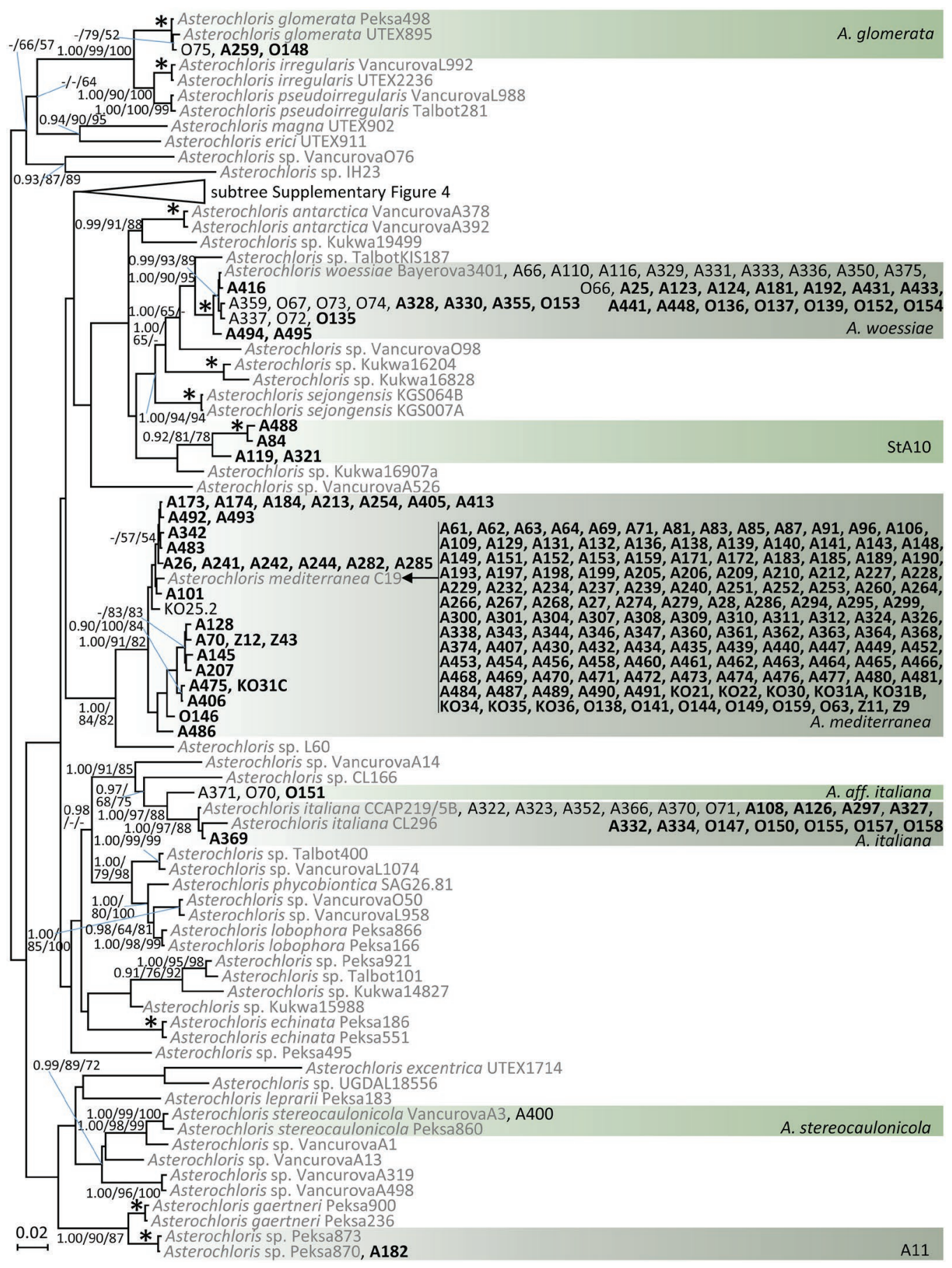

FIGURE 2 | Phylogenetic hypothesis (unrooted tree) of Asterochloris resulting from Bayesian analysis of ITS rDNA. Values at the nodes indicate the statistical supports of Bayesian posterior probability (left), maximum-likelihood bootstrap (middle) and maximum parsimony bootstrap (right). Scale bar shows the estimated number of substitutions per site. Newly obtained sequences are marked in bold. We selected the reference sequences from GenBank (in grey; accession numbers are listed in Supplementary Table 4) taking care to include all known Asterochloris species as well as other previously published Asterochloris species-level lineages. The collapsed clade is displayed in Supplementary Figure 4.

Canaria. On La Palma and Lanzarote, all three Vulcanochloris species were present. Interestingly, Vulcanochloris phycobionts were found exclusively in association with $S$. canariense (Figure 6B).

\section{Climatic Niches}

We constructed two-dimensional (PC1-PC2, explaining $82.4 \%$ of the variation in climatic variables) hypervolumes for the six most abundant algal species-level lineages and the three 


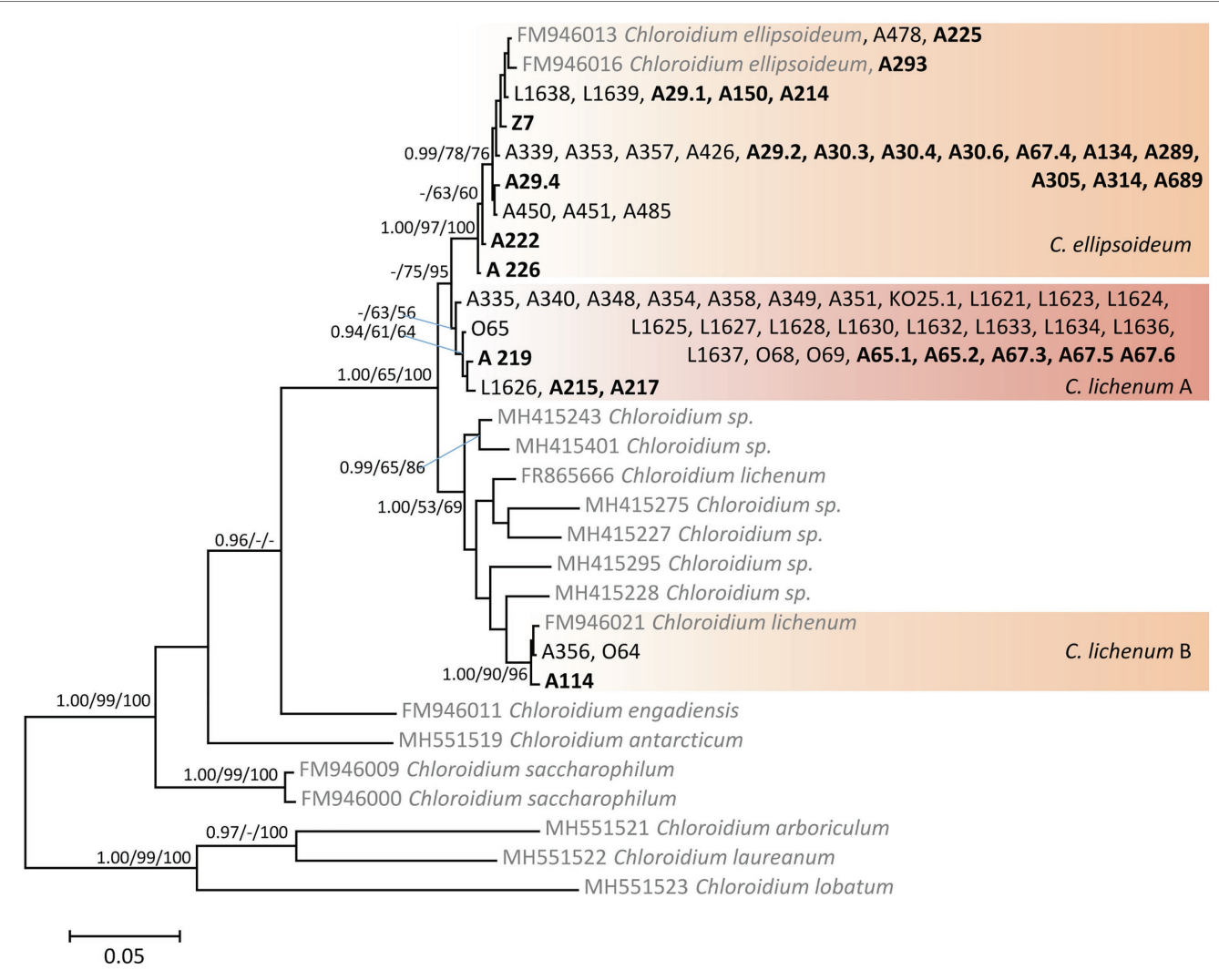

FIGURE 3 | Phylogenetic hypothesis (unrooted tree) of Chloroidium resulting from Bayesian analysis of ITS rDNA. Values at the nodes indicate the statistical supports of Bayesian posterior probability (left), maximum-likelihood bootstrap (middle) and maximum parsimony bootstrap (right). Scale bar shows the estimated number of substitutions per site. Newly obtained sequences are marked in bold, reference sequences from GenBank are in grey.



FIGURE 4 | Phylogenetic hypothesis (unrooted tree) of Vulcanochloris resulting from Bayesian analysis of ITS rDNA. Values at the nodes indicate the statistical supports of Bayesian posterior probability (left), maximum-likelihood bootstrap (middle) and maximum parsimony bootstrap (right). Fully supported branches $(1.0 / 100 / 100)$ are marked with an asterisk. Scale bar shows the estimated number of substitutions per site. Newly obtained sequences are marked in bold, reference sequences from GenBank are in grey. 


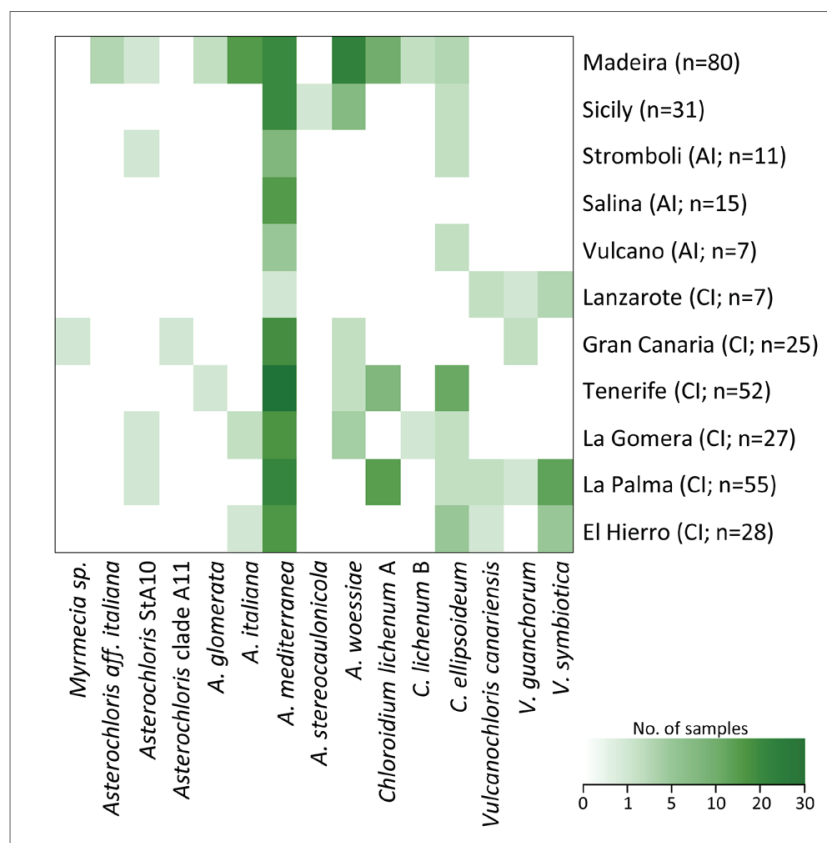

FIGURE 5 | Distribution of phycobiont species-level lineages on particular islands within the study area. Number of samples is indicated in brackets. Al, Aeolian Islands and Cl, Canary Islands.

most abundant Stereocaulon mycobiont species-level lineages. Since the climatic characteristics differed considerably between Macaronesia and the Mediterranean region, the hypervolumes split into two isolated parts. Within each of them, there was a gradient of climatic niches along PC1, representing mostly the gradients of temperature and precipitation (Figure 7).

Among the algal species-level lineages, Vulcanochloris symbiotica tolerated the driest and warmest climate. On the other hand, Asterochloris woessiae, A. italiana, and Chloroidium lichenum A were distributed predominantly in the more humid and relatively colder areas. Asterochloris mediterranea and C. ellipsoideum were widely distributed in warm and dry areas and their climatic niches partly overlapped with that of both sides of the continuum. Climatic niches of $A$. mediterranea, C. ellipsoideum, and A. woessiae involved the whole range of temperature and precipitation seasonality (corresponding roughly with PC2). Remarkably, the niches of A. mediterranea and C. ellipsoideum overlapped to a large extent. Similarly, the niches of A. italiana and C. lichenum A were equivalent.

The climatic hypervolume of $S$. vesuvianum was the widest among Stereocaulon species. It included the whole range of temperature seasonality in Macaronesia as well as that of the Mediterranean region. The warmest and driest areas with high precipitation seasonality were dominated by S. canariense. The climatic niche of $S$. azoreum overlapped with part of that of S. vesuvianum. These two species likely differed in microclimatic factors (not included in this study).

Finally, we focused on the niche of the most abundant phycobiont in the study area, A. mediterranea. We inspected the differences between the climatic requirements of this species and those of other Asterochloris species associated with either two dominant mycobiont species (Cladonia rangiformis and Stereocaulon azoreum) or all mycobionts using Welch's $t$-tests. Similarly, we tested the differences between Chloroidium ellipsoideum and C. lichenum A. Table 2 summarizes the results of the tests performed for various combinations of phycobionts and mycobionts. The means of three variables showed significant differences $(\alpha=0.01)$ across all combinations: BIO1 - annual mean temperature, BIO8 - mean temperature of the wettest quarter, and BIO11 mean temperature of the coldest quarter (Figure 8). In contrast, we did not find any significant difference between the groups in $\mathrm{BIO} 3$ [Isothermality (BIO2/BIO7)] and $\mathrm{BIO} 4$ (Temperature Seasonality) climatic variables.

Interestingly, along the gradient of annual mean temperature, A. mediterranea was replaced by other Asterochloris species at different temperature levels depending on whether it was associated with Stereocaulon azoreum or C. rangiformis (the later in about $1^{\circ} \mathrm{C}$ colder temperature). Furthermore, C. ellipsoideum was replaced by $C$. lichenum A at an annual mean temperature of approximately $13^{\circ} \mathrm{C}$ (Figure 8).

\section{Taxonomy}

Stereocaulon canariense Malíček \& Vančurová sp. nov. Mycobank: MB841859.

\section{Type}

Spain, Canary Islands. El Hierro, Parque rural de Frontera, Ermita de los Reyes, N-facing lava field, $27^{\circ} 43^{\prime} 48.9^{\prime \prime} \mathrm{N}$, $18^{\circ} 07^{\prime} 13.6^{\prime \prime} \mathrm{W}$, alt. $710 \mathrm{~m}$, on lava rock, leg. L. Vančurová \& J. Malíček 16. 5. 2013 (holotype - PRA-00020984; isolate A313). ITS GenBank number OL625487.

\section{Diagnosis}

Almost identical with S. vesuvianum s. str., but calcium oxalate crystals absent from apothecia and both species differ in molecular characters of nuclear ITS region.

\section{Etymology}

Distribution of the new species is restricted to the Canary Islands.

\section{Description}

Podetia up to $3.5 \mathrm{~cm}$, (richly) branched, smooth and without tomentum or rarely with rudimental local tomentum on the underside. Cephalodia not observed, but small bunches of Stigonema on podetia observed in three collections. In exposed habitats, podetia are usually low and forming more or less compact cushions covered by phyllocladia or even only basal thallus composed of phyllocladia present. Phyllocladia densely cover podetia or form basal thallus in young stages, developing from small white to pale grey granules/squamules without the dark center to typical peltate shape with a distinct white rim and olive center, resembling lecanorine apothecia, up to $1.5 \mathrm{~mm}$ 


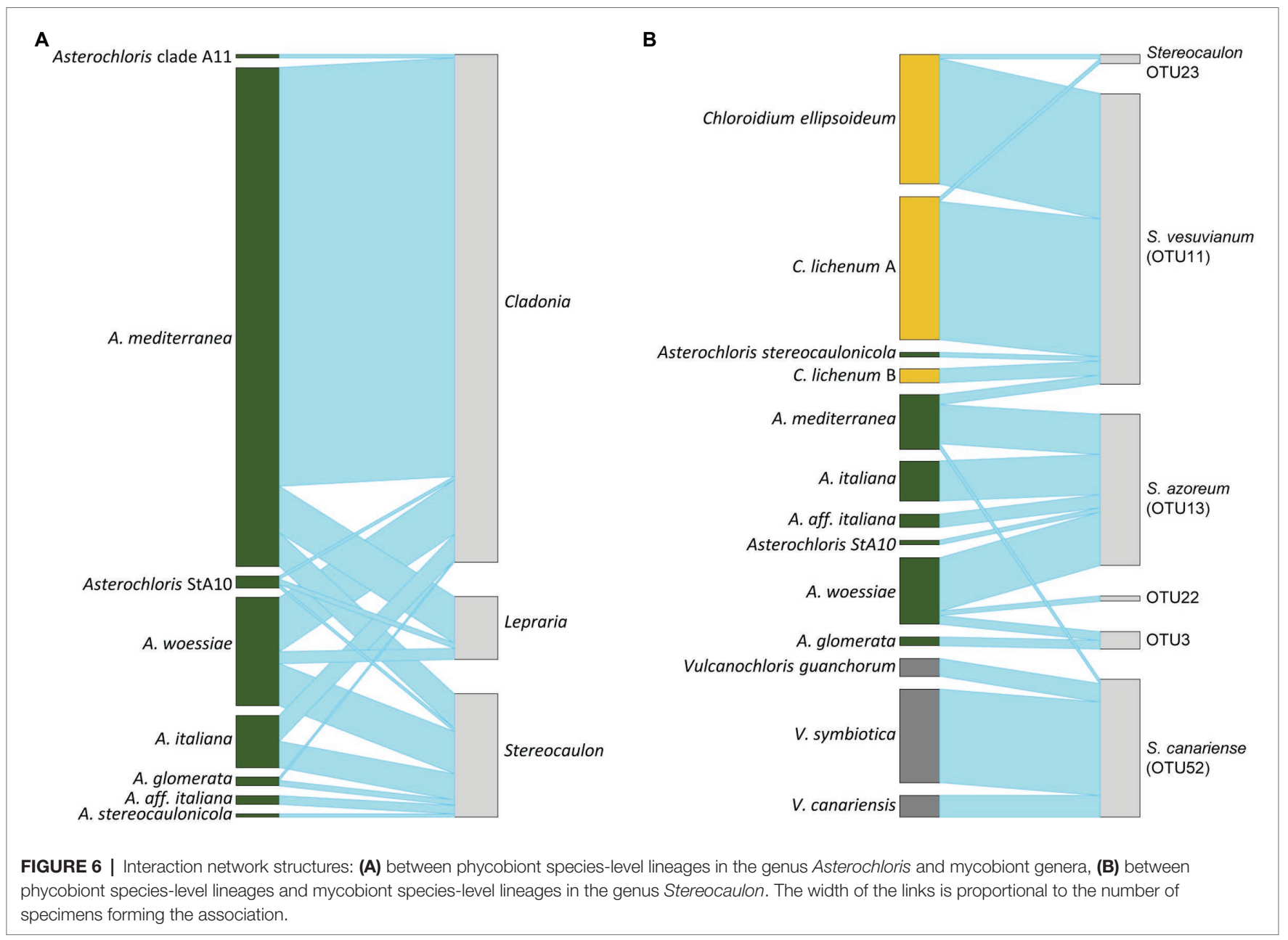

in diam (Figure 9A). Margin of phyllocladia elevated, flexuose to rarely crenulate, thick. Hyphal tissue in the olive center of phyllocladia 50-100 (-130) $\mu \mathrm{m}$ thick in section, colorless to yellowish/brownish in upper part due to crystals of atranorin (soluble in $\mathrm{K}$ ), which are very abundant in this layer and upper part of phyllocladia margin, photobiont cells $7-13 \mu \mathrm{m}$ in diam., medullary hyphae branched, $8-15 \mu \mathrm{m}$ thick, walls $3-6 \mu \mathrm{m}$ thick.

Apothecia common in well-developed thalli, lecideine, brown to black, $0.4-0.6 \mathrm{~mm}$ in diam., sessile to constricted at base, discs firstly plane, soon convex. Outer exciple pale brown (rarely) to brown, of thick hyphae (c. $10 \mu \mathrm{m}$ ), with abundant fine crystals of atranorin $(\mathrm{POL}+$, soluble in $\mathrm{K}$ ); hypothecium very pale brown to brown, $\mathrm{K}+$ yellow-brown to dark brown, without crystals; epihymenium brown, POL+ but without any crystalline objects (POL- in K); hymenium 50-75 (-100) $\mu \mathrm{m}$. Paraphyses $1-2 \mu \mathrm{m}$ thick, sparsely branched, swollen at tips up to $4(-5) \mu \mathrm{m}$, apices often with a dark brown cap. Asci 8-spored, clavate, ca. 35-40×8-12 (-14) $\mu \mathrm{m}$. Ascospores 1-3-septate, (18-) 23-35×2.5-3.5 $\mu \mathrm{m}$, colorless, straight or slightly curved, with rounded apices.

Pycnidia infrequent, in phyllocladia near podetia apices, black, variable in shape, usually $100-200 \mu \mathrm{m}$ in diam. (in section), wall brown, paraplectenchymatic, conidia straight or one apex slightly curved, $5-7 \times 1 \mu \mathrm{m}$.

\section{Chemistry}

Atranorin (major), stictic acid complex (major), including norstictic acid (minor) detected by TLC $(n=24)$. Spot reactions: $\mathrm{K}+$ yellow, $\mathrm{Pd}+$ slowly orange, $\mathrm{C}-, \mathrm{KC}-, \mathrm{UV}+$ dull (yellow-)orange.

\section{Distribution and Ecology}

The new species is so far known only from the Canary Islands (Gran Canaria, El Hierro, La Palma, Lanzarote, Tenerife). Most of records come from La Palma, El Hierro and Lanzarote. It is common and widely distributed here in lower and middle elevations from $100 \mathrm{ma.s.l}$. (Gran Canaria) to $960 \mathrm{~m}$ a.s.l. (Tenerife). It occurs on lava rocks, where it is among the first colonists. In some areas, it may be a dominant in saxicolous communities. Rarely, it may grow on soil crusts in volcanic rocks or weathered lava ground.

Caloplaca spp. and Candelariella vitellina were the most commonly recorded, co-occurring species. Acarospora spp., Buellia spp., Cladonia foliacea, Cetraria aculeata, Lecanora campestris, and Ramalina spp. were other associated taxa. 
A

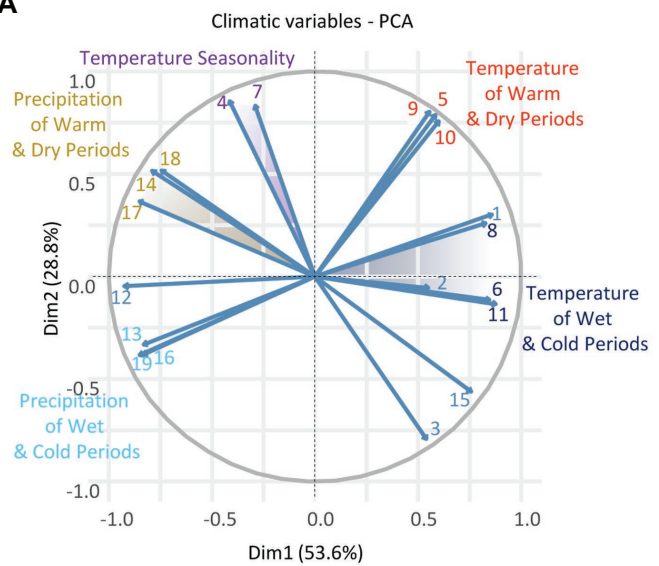

B

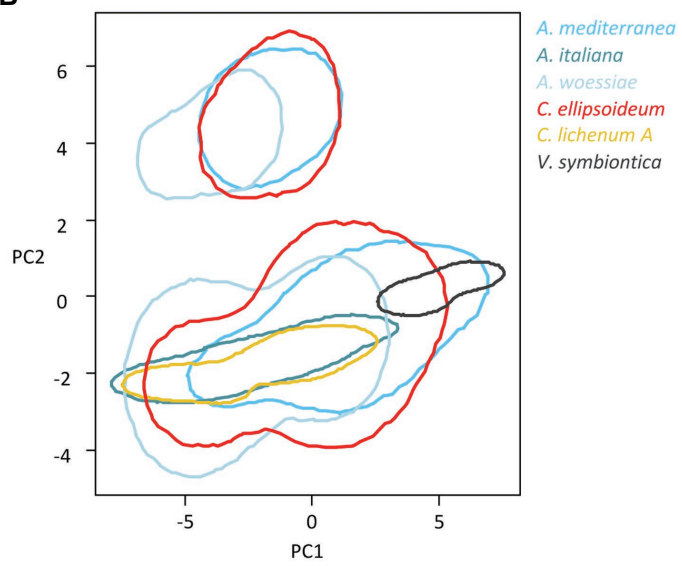

C

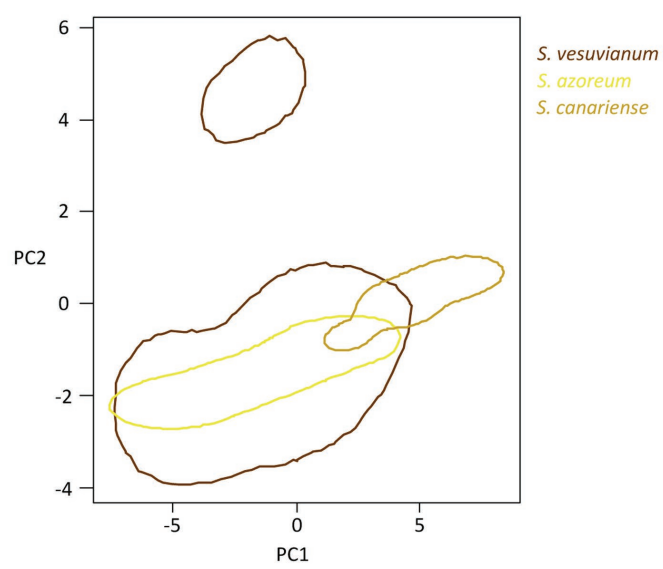

FIGURE 7 | (A) Principal coordinate analysis of 19 Bioclim variables: $1=$ annual mean temperature, $2=$ mean diurnal range, $3=$ isothermality, $4=$ temperature seasonality, $5=$ max temperature of warmest month, $6=$ min temperature of coldest month, $7=$ temperature annual range, $8=$ mean temperature of wettest quarter, $9=$ mean temperature of driest quarter, $10=$ mean temperature of warmest quarter, $11=$ mean temperature of coldest quarter, $12=$ annual precipitation, 13=precipitation of wettest month, $14=$ precipitation of driest month, $15=$ precipitation seasonality, $16=$ precipitation of wettest quarter, $17=$ precipitation of driest quarter, $18=$ precipitation of warmest quarter, $19=$ precipitation of coldest quarter. Climatic niche hypervolumes for (B) six most abundant phycobiont species-level lineages and (C) three most abundant Stereocaulon mycobiont species-level lineages.
TABLE 2 | Results of Welch's $t$-tests ( $p$ ) performed for contrasting pairs of phycobionts in combination with their mycobionts.

\begin{tabular}{|c|c|c|c|c|}
\hline $\begin{array}{l}\text { Climatic } \\
\text { variable }\end{array}$ & $\begin{array}{c}\text { Asterochloris } \\
\text { mediterranea } \\
\text { with other } \\
\text { Asterochloris } \\
\text { spp. in } \\
\text { association } \\
\text { with all } \\
\text { mycobionts }\end{array}$ & $\begin{array}{l}\text { Asterochloris } \\
\text { mediterranea } \\
\text { with other } \\
\text { Asterochloris } \\
\text { spp. in } \\
\text { association } \\
\text { with } \\
\text { Cladonia } \\
\text { rangiformis }\end{array}$ & $\begin{array}{l}\text { Asterochloris } \\
\text { mediterranea } \\
\text { with other } \\
\text { Asterochloris } \\
\text { spp. in } \\
\text { association } \\
\text { with } \\
\text { Stereocaulon } \\
\text { azoreum }\end{array}$ & $\begin{array}{c}\text { Chloroidium } \\
\text { ellipsoideum } \\
\text { with C. } \\
\text { lichenum A } \\
\text { in } \\
\text { association } \\
\text { with } \\
\text { Stereocaulon } \\
\text { vesuvianum }\end{array}$ \\
\hline $\mathrm{BlO} 1$ & $3.9 e^{-16}$ & 0.000108 & 0.000252 & $3.861 \mathrm{e}^{-06}$ \\
\hline $\mathrm{BlO} 2$ & $1.221 \mathrm{e}^{-07}$ & 0.8077 & $6.786 \mathrm{e}^{-07}$ & 0.4361 \\
\hline $\mathrm{BIO} 3$ & 0.4156 & 0.1005 & 0.7618 & 0.2455 \\
\hline $\mathrm{BlO} 4$ & 0.0481 & 0.1083 & 0.0193 & 0.108 \\
\hline $\mathrm{BIO5}$ & $<2.2 \mathrm{e}^{-16}$ & 0.3672 & $1.888 e^{-09}$ & $5.156 e^{-06}$ \\
\hline $\mathrm{BlO} 6$ & $6.366 e^{-07}$ & 0.0005975 & 0.01907 & 0.0003686 \\
\hline $\mathrm{BlO} 7$ & 0.001919 & 0.1031 & 0.0001044 & 0.06981 \\
\hline $\mathrm{BlO} 8$ & $1.728 e^{-14}$ & $1.019 e^{-05}$ & 0.009172 & $5.103 e^{-06}$ \\
\hline $\mathrm{BlO9}$ & $<2.2 \mathrm{e}^{-16}$ & 0.3203 & $7.36 e^{-07}$ & $4.267 e^{-06}$ \\
\hline $\mathrm{BlO} 10$ & $<2.2 \mathrm{e}^{-16}$ & 0.1695 & $2.584 \mathrm{e}^{-06}$ & $3.523 e^{-06}$ \\
\hline $\mathrm{BlO} 11$ & $1.231 \mathrm{e}^{-07}$ & 0.001109 & 0.003458 & 0.0003848 \\
\hline $\mathrm{BlO} 12$ & $5.331 e^{-13}$ & 0.1466 & $3.869 e^{-10}$ & 0.02286 \\
\hline $\mathrm{BIO13}$ & $7.446 e^{-13}$ & 0.3267 & $1.421 e^{-06}$ & $7.618 e^{-05}$ \\
\hline $\mathrm{BIO} 14$ & $9.298 e^{-06}$ & 0.07341 & $4.231 e^{-10}$ & 0.9307 \\
\hline $\mathrm{BlO} 15$ & $7.683 e^{-05}$ & 0.09019 & $5.233 e^{-12}$ & 0.7347 \\
\hline $\mathrm{BIO16}$ & $1.527 e^{-13}$ & 0.3982 & $1.63 e^{-07}$ & $6.214 e^{-05}$ \\
\hline $\mathrm{BIO} 17$ & $1.337 e^{-08}$ & 0.065 & $9.763 e^{-11}$ & 0.617 \\
\hline $\mathrm{BIO18}$ & $9.482 e^{-05}$ & 0.1287 & $4.408 e^{-11}$ & 0.9033 \\
\hline $\mathrm{BIO} 19$ & $2.164 e^{-14}$ & 0.379 & $5.673 e^{-07}$ & $3.624 e^{-05}$ \\
\hline Altitude & $2.977 e^{-08}$ & 0.05307 & 0.09813 & 0.003085 \\
\hline
\end{tabular}

Bioclim variables: $1=$ annual mean temperature, $2=$ mean diurnal range,

$3=$ isothermality, $4=$ temperature seasonality, $5=$ max temperature of warmest month, $6=$ min temperature of coldest month, $7=$ temperature annual range, $8=$ mean temperature of wettest quarter, $9=$ mean temperature of driest quarter, $10=$ mean temperature of warmest quarter, $11=$ mean temperature of coldest quarter, $12=$ annual precipitation, $13=$ precipitation of wettest month, $14=$ precipitation of driest month, $15=$ precipitation seasonality, $16=$ precipitation of wettest quarter, $17=$ precipitation of driest quarter, $18=$ precipitation of warmest quarter, $19=$ precipitation of coldest quarter.

\section{Phylogeny}

Stereocaulon canariense is strongly supported as a distinct clade in the ITS phylogeny; its closest relative is S. virgatum (Figure 1). The most similar species, S. vesuvianum s. str. (OTU11) and the boreal-montane to arctic-alpine $S$. vesuvianum var. nodulosum are (OTU10) not closely related.

\section{Notes}

Stereocaulon canariense is quite a variable species. Thalli on very dry and exposed sites are often formed by low compact cushions of podetia or even by phyllocladia alone. One sample (L1617) was composed mostly of phyllocladia, forming the basal thallus, with abundant apothecia and rare podetia up to $3 \mathrm{~mm}$ high. In two samples (A315 and A169), local "pseudosoralia" were observed. They contained white blastidia like structures of c. $0.1 \mathrm{~mm}$ in diam. with compact hyphae on their surface.

Stereocaulon vesuvianum sensu lato is a very polymorphic and cosmopolitan morphospecies well characterized by its peltate phyllocladia (grey to olive in centers) and the presence of stictic acid (Lamb, 1977). However, our molecular studies 




B

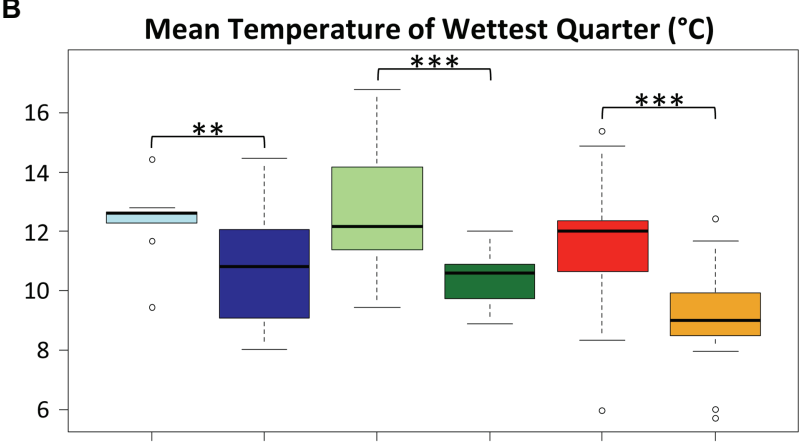

C

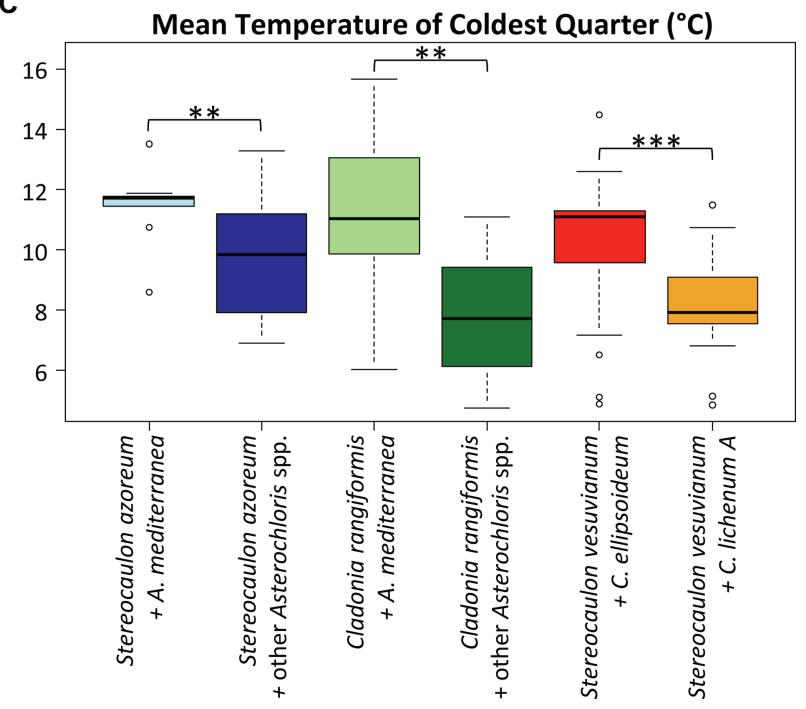

FIGURE 8 | Differences in the distribution of selected phycobiont-mycobiont pairs along the gradients of (A) annual mean temperature, (B) mean temperature of wettest quarter, and (C) mean temperature of coldest quarter. Significance level: two stars (**): $p<0.01$, three stars $(* * *): p<0.001$.

revealed three distinct lineages in the complex. Here we described only $S$. canariense, but the other taxa should be re-classified in the future. Stereocaulon vesuvianum sensu stricto is morphologically identical, but contains calcium oxalate crystals in lower hypothecium. We observed two additional characters, which, however, partially overlap in both species. Epihymenium in S. vesuvianum is usually reddish-brown (brown in S. canariense) and phyllocladia form generally smaller olive centers, which are often poorly developed or only punctiform comparing to usually large olive centers in S. canariense, and its phyllocladia strongly resembling lecanorine apothecia. Both species share similar ecology, but on the Canary Islands, they have not been collected at the same site. Most of localities of S. vesuvianum have been recorded above $1,000 \mathrm{~m}$ a.s. 1 . (mean $=1,426 \mathrm{~m}, n=32$ ), whereas $S$. canariense occurs below this elevation (mean $=476 \mathrm{~m}$, $n=25$ ). Stereocaulon vesuvianum is not restricted to young stages of lava fields, but grows on various volcanic rocks also in late succession stages, e.g., well-lit forests with rocky substrata.

The most widely distributed lineage of "S. vesuvianum" (OTU10) well corresponds to var. nodulosum (Wallr.) Lamb, described also as S. denudatum Flörke (Lamb, 1977), which is characterized by rare apothecia, frequent globose soralia at tips (usually present at well-developed samples) and the absence of calcium oxalate crystals in apothecia. Its podetia are simple or sparsely branched, usually in upper half. This taxon distinctly differs from Mediterranean S. vesuvianum s. str. in ecology: it is a boreal-montane to arctic-alpine species, occurring usually on acidic siliceous stones and rocks.

\section{Additional Specimens Examined: SPAIN, Canary Islands}

El Hierro: $1.9 \mathrm{~km}$ NNE of Faro de Orchilla, lava field, $27^{\circ} 43^{\prime} 24.6^{\prime \prime} \mathrm{N}, 18^{\circ} 8^{\prime} 43.4^{\prime \prime} \mathrm{W}$, alt. $280 \mathrm{~m}$, leg. L. Vančurová \& J. Malíček 16. 5. 2013 (PRA; A315); 3 km NNW of La Restinga, lava field, $27^{\circ} 39^{\prime} 57.5^{\prime \prime} \mathrm{N}, 17^{\circ} 59^{\prime} 38.6^{\prime \prime} \mathrm{W}$, alt. $330 \mathrm{~m}$, leg. L. Vančurová \& J. Malíček 15. 5. 2013 (PRA; A290, A291); El Hierro, El Sabinar, heap of stones, soil and lava stones, 27.7454517N, 18.1229275 W, alt. $665 \mathrm{~m}$, leg. J. Vančurová 5. 3. 2020 (PRA; A690). Gran Canaria: Agaete, ancient necropolis, lava field, $28^{\circ} 05^{\prime} 49.2^{\prime \prime} \mathrm{N}, 15^{\circ} 41^{\prime} 30.9^{\prime \prime} \mathrm{W}$, alt. $100 \mathrm{~m}$, leg. L. Vančurová \& J. Malíček 2. 6. 2013 (PRA; A201, A202). La Palma: $2.5 \mathrm{~km}$ NE from Puerto de Naos, lava field, $28^{\circ} 36^{\prime} 17.0^{\prime \prime} \mathrm{N}$, $17^{\circ} 53^{\prime} 43.4^{\prime \prime} \mathrm{W}$, alt. $440 \mathrm{~m}$, leg. L. Vančurová \& J. Malíček 20. 5. 2013 (PRA; A104); Ibid.: 28 $35^{\prime} 55.7^{\prime \prime} \mathrm{N}, 17^{\circ} 53^{\prime} 36.2^{\prime \prime} \mathrm{W}$, alt. 480 m, leg. L. Vančurová \& J. Malíček 20. 5. 2013 (PRA; A105); $3 \mathrm{~km}$ E of El Paso, lava rock on the border of the $\mathrm{N}$-facing lava field, $28^{\circ} 39^{\prime} 11.4^{\prime \prime} \mathrm{N}, 17^{\circ} 51^{\prime} 4.3^{\prime \prime} \mathrm{W}$, alt. $860 \mathrm{~m}$, leg. L. Vančurová \& J. Malíček 19. 5. 2013 (PRA; A97); Ibid.: 28³9'10.1"N, $17^{\circ} 51^{\prime} 4.3^{\prime \prime} \mathrm{W}$, alt. $865 \mathrm{~m}$, leg. L. Vančurová \& J. Malíček 19. 5. 2013 (PRA; A98); at base of volcano San Antonio, lava stone, $28^{\circ} 28^{\prime} 39.7^{\prime \prime} \mathrm{N}, 17^{\circ} 51^{\prime} 1.3^{\prime \prime} \mathrm{W}$, alt. $390 \mathrm{~m}$, leg. L. Vančurová \& J. Malíček 17. 5. 2013 (PRA; A77); at base of volcano Teneguía, little lava stones around the path, $28^{\circ} 27^{\prime} 50.9^{\prime \prime} \mathrm{N}, 17^{\circ} 50^{\prime} 43.2^{\prime \prime} \mathrm{W}$, alt. $175 \mathrm{~m}$, leg. L. Vančurová \& J. Malíček 17. 5. 2013 (PRA; A80); Santa Cruz de La Palma, San Isidro, E-slope of mountain ridge Cumre Nueva just above the village, weathered volcanic rock, $28^{\circ} 37^{\prime} 49^{\prime \prime} \mathrm{N}, 17^{\circ} 48^{\prime} 1^{\prime \prime} \mathrm{W}$, alt. $675 \mathrm{~m}$, leg. J. Vondrák 16. 3. 2014 (PRA-Vondrák 12,151; O56); Volcan Teneguía, lava stone by the path, $28^{\circ} 28^{\prime} 23^{\prime \prime} \mathrm{N}, 17^{\circ} 50^{\prime} 50^{\prime \prime} \mathrm{W}$, alt. $340 \mathrm{~m}$, leg. L. Vančurová 16. 10. 2011 (PRA; L1620); volcano San Antonio, stone on the top of a volcano, $28^{\circ} 29^{\prime} 7.8^{\prime \prime} \mathrm{N}, 17^{\circ} 50^{\prime} 59.7^{\prime \prime} \mathrm{W}$, alt. $610 \mathrm{~m}$, leg. L. Vančurová \& J. Malíček 17. 5. 2013 (PRA; A72, A73); Ibid.: little lava stones around the path, $28^{\circ} 29^{\prime} 13.8^{\prime \prime} \mathrm{N}$, $17^{\circ} 50^{\prime} 56.9^{\prime \prime} \mathrm{W}$, alt. $630 \mathrm{~m}$, leg. L. Vančurová \& J. Malíček 17. 5. 2013 (PRA; A74); Ibid.: 28 $29^{\prime} 11.4^{\prime \prime} \mathrm{N}, 17^{\circ} 50^{\prime} 59.2^{\prime \prime} \mathrm{W}$, alt. 
A

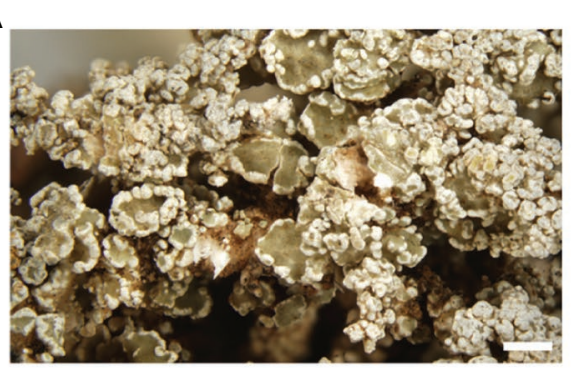

C

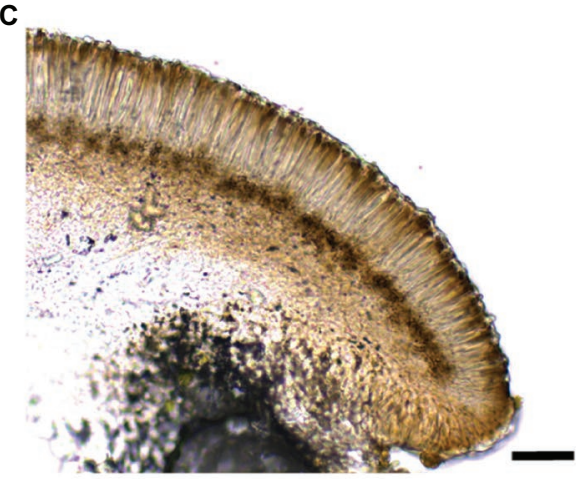

E

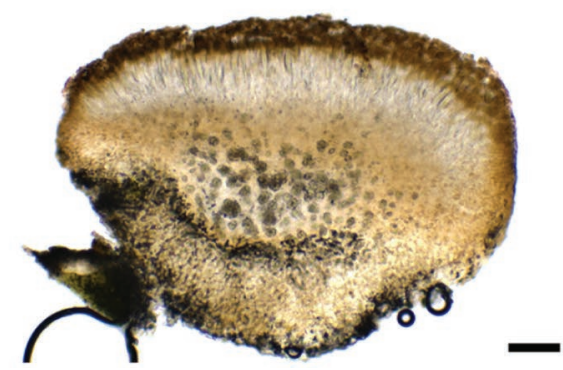

B

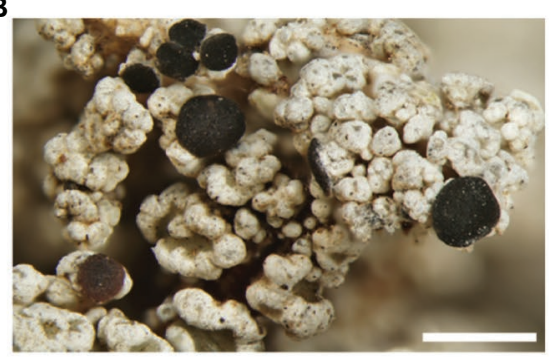

D

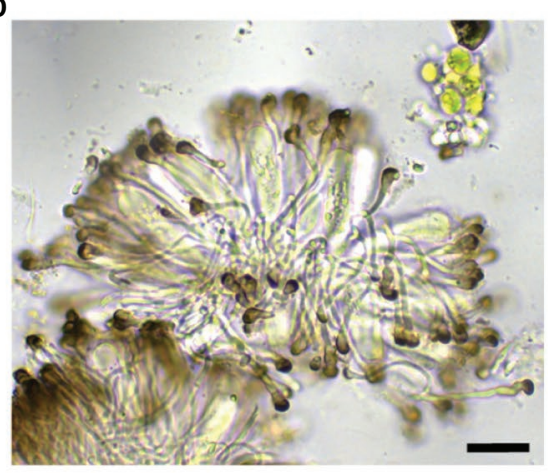

$\mathbf{F}$

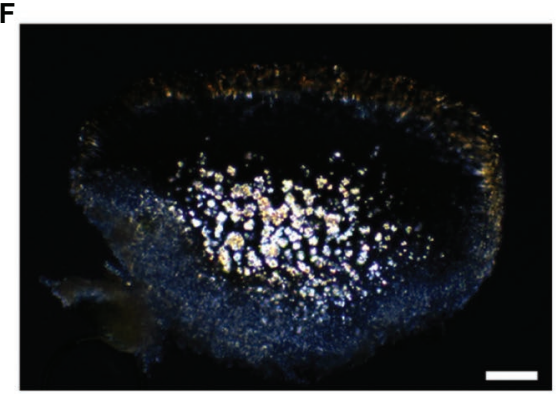

FIGURE 9 | Habitus of Stereocaulon canariense (A-D) and Stereocaulon vesuvianum s. str. (E,F). (A) Typical peltate phyllocladia, holotype; (B) fertile podetia, holotype; (C) section of an apothecium in water; (D) paraphyses with brown apical cap in $\mathrm{KOH}$; (E) section of an apothecium in water; (F) section of an apothecium in polarized light. Scales: $1 \mathrm{~mm}$ (A,B), $50 \mu \mathrm{m}$ (C-F), $20 \mu \mathrm{m}$ (D).

615 m, leg. L. Vančurová \& J. Malíček 17. 5. 2013 (PRA; A75); Ibid.: $28^{\circ} 28^{\prime} 55^{\prime \prime} \mathrm{N}, 17^{\circ} 50^{\prime} 58^{\prime \prime} \mathrm{W}$, alt. $595 \mathrm{~m}$, leg. L. Vančurová 16. 10. 2011 (PRA; L1616); Ibid.: $28^{\circ} 28^{\prime} 53^{\prime \prime} \mathrm{N}, 17^{\circ} 50^{\prime} 44^{\prime \prime} \mathrm{W}$, alt. 480 m, leg. L. Vančurová 16. 10. 2011 (PRA; L1617, L1618); volcano Teneguía, lava rock, $28^{\circ} 28^{\prime} 29.0^{\prime \prime} \mathrm{N}, 17^{\circ} 51^{\prime} 3.7^{\prime \prime} \mathrm{W}$, alt. 380 m, leg. L. Vančurová \& J. Malíček 17. 5. 2013 (PRA; A78). Lanzarote: Paisaje Protegido de La Geria, lava field, $28^{\circ} 59^{\prime} 1.4^{\prime \prime} \mathrm{N}$, $13^{\circ} 40^{\prime} 53.5^{\prime \prime} \mathrm{W}$, alt. $330 \mathrm{~m}$, leg. L. Vančurová \& J. Malíček 25. 5. 2013 (PRA; A169); Parque Natural de Los Volcanes, lava field, $29^{\circ} 2^{\prime} 39.6^{\prime \prime} \mathrm{N}, 13^{\circ} 42^{\prime} 32.4^{\prime \prime} \mathrm{W}$, alt. $240 \mathrm{~m}$, leg. L. Vančurová \& J. Malíček 24. 5. 2013 (PRA; A162); Ibid.: 292'27.9"N,

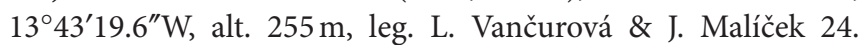
5. 2013 (PRA; A163); Ibid.: 29 $0^{\prime} 50.6^{\prime \prime} \mathrm{N}, 13^{\circ} 43^{\prime} 51.5^{\prime \prime} \mathrm{W}$, alt. 300 m, leg. L. Vančurová \& J. Malíček 24. 5. 2013 (PRA; A164, A165); Ibid.: $29^{\circ} 2^{\prime} 38.5^{\prime \prime} \mathrm{N}, 13^{\circ} 43^{\prime} 22.5^{\prime \prime} \mathrm{W}$, alt. $205 \mathrm{~m}$, leg. L. Vančurová \& J. Malíček 24. 5. 2013 (PRA; A167). Tenerife: Arguayo, near soccer field, N-facing lava field, $28^{\circ} 16^{\prime} 20.4^{\prime \prime} \mathrm{N}$, $16^{\circ} 48^{\prime} 18.8^{\prime \prime} \mathrm{W}$, alt. $960 \mathrm{~m}$, leg. L. Vančurová \& J. Malíček 7. 5. 2013 (PRA; A254).

\section{DISCUSSION}

\section{Phycobiont Diversity in the Study Area}

We found 15 species-level lineages of phycobionts in 338 lichen thalli belonging to the genera Stereocaulon, Cladonia, and Lepraria. Out of these 15 lineages, only eight belonged to the genus Asterochloris. This is a relatively surprising finding considering the results of previous studies focusing on photobiont diversity of corresponding mycobiont genera. For example, Kosecka et al. (2021) found 21 Asterochloris and one Vulcanochloris species-level lineages in Bolivia with a considerably smaller sampling of the same lichen genera. Vančurová et al. (2020) sampled only two Stereocaulon species-level lineages in 
the Swiss Alps and found 14 Asterochloris and three other trebouxiophycean species-level lineages. Peksa and Škaloud (2011) recovered 10 Asterochloris lineages associated with Lepraria in the Czech Republic. In the study area, globally abundant Asterochloris species (Asterochloris irregularis, A. pseudirregularis, A. lobophora, A. phycobiontica, A. gaertneri, A. friedlii, and others) were not detected. One of the most common Asterochloris species, A. glomerata (Pino-Bodas and Stenroos, 2020), was present in three samples and belonged to the single genotype that is known to be exclusively from the study area.

We hypothesized that the isolation of oceanic islands may explain the limited phycobiont species richness. However, the islands in Macaronesia showed higher species richness than the less isolated Sicily and Aeolian Islands. It is more likely that phycobiont distribution can be restricted by a limited number of substrate/habitat types. The main reason for the absence of many Asterochloris lineages might be their preference for cold and wet climates (Vančurová et al., 2018; Pino-Bodas and Stenroos, 2020). Nevertheless, there were a few cases in which phycobionts that are typical of cold climates were recorded; for example, one sample included A. stereocaulonicola, which was originally described in Antarctica (Kim et al., 2020). In contrast, A. mediterranea, the most abundant phycobiont in the study area, copes well with warm and dry climates (Moya et al., 2015; Pino-Bodas and Stenroos, 2020). Madeira, the wettest and coldest island in our study, showed the highest phycobiont species richness. Interestingly, we found all three Vulcanochloris species with a high haplotype diversity on the warmest and driest island in the study area, Lanzarote. This island seemed to be the hot-spot of Vulcanochloris diversity. In contrast, lichens associated with Asterochloris (including A. mediterranea, which performs well in warmer habitats) were extremely rare in that island. Lindgren et al. (2020) proposed a hypothesis explaining the association between Haveochlorella and several Sticta spp. on Madagascar and Reunion. A longdistance dispersal of mycobionts may have been followed by an association with locally adapted phycobionts and the subsequent diversification of mycobionts. This pattern can be true also for the relationship between $S$. canariense and Vulcanochloris spp.

In one case, we noticed Myrmecia sp. as the phycobiont of Cladonia. The genus Asterochloris has generally been considered the exclusive phycobiont of this broadly distributed mycobiont genus (Piercey-Normore and DePriest, 2001; Yahr et al., 2006; Steinová et al., 2019; Pino-Bodas and Stenroos, 2020). However, its ability to associate with Trebouxia and Chloroidium under stressful conditions has recently been demonstrated (Park et al., 2015; Osyczka et al., 2020). Moreover, Elshobary et al. (2015) discovered unknown trebouxiophycean algae as phycobionts of Cladonia macrophylla.

\section{Phycobiont Pool Sharing}

Kaasalainen et al. (2021) demonstrated that cyanolichens share photobionts and revealed the presence of photobiontmediated lichen guilds. Most of the mycobionts shared photobionts with other non-related fungal species but other photobiont-mycobiont pairs remained isolated. In our study area, the vast majority of Cladonia and Lepraria mycobionts associated with the $A$. mediterranea phycobiont. On the other hand, phycobionts of Stereocaulon were highly diverse. After downsampling to a sample size of 22 (the number of Lepraria samples) Stereocaulon mycobionts associated with almost two times more phycobiont species than Cladonia or Lepraria (Supplementary Figure 5). The Stereocaulon species-level lineages showed a high level of specificity towards their phycobionts (on the level of algal genera, but not on the level of algal species). Stereocaulon azoreum was associated with the same phycobionts as Cladonia and Lepraria on the Canary Islands, whereas in Madeira, it associated with another algal species. Stereocaulon vesuvianum and $S$. canariense were associated with Chloroidium spp. and Vulcanochloris spp., respectively. Although Cladonia and Lepraria mycobionts often grow together with Stereocaulon mycobionts, S. vesuvianum and S. canariense never shared phycobionts with them in our samples. Moreover, at localities where more than one thallus was sampled with Asterochloris, the number of species-level lineages varied. In some cases, all samples shared one species, but at other localities, each sample contained different species of Asterochloris.

Stereocaulon is not the only mycobiont genus able to associate with various phycobiont genera. The mycobiont genus Sticta has been shown to associate (besides cyanobacteria) with multiple trebouxiophycean algae (Haveochlorella, Chloroidium, Symbiochloris, and Elliptochloris); some Sticta species are specific towards particular phycobionts, but others can associate with up to three trebouxiophycean genera (Lindgren et al., 2020). Previous studies hypothesized that Chloroidium phycobionts are well-adapted to volcanic substrates (Vančurová et al., 2018). However, Cladonia mycobionts in association with Asterochloris can also cope with this substrate. This fact points to the role of specificity or other mycobiont features on phycobiont distribution. On the other hand, S. canariense was able to grow at arid localities in association with Vulcanochloris spp. Nevertheless, we could not find any lichen usually associated with Asterochloris (Cladonia and Lepraria) in the most arid parts of the study area (Fuerteventura and most of the localities on Lanzarote), even though these have previously been reported (van den Boom and Etayo, 2006). In contrast, the driest areas were dominated by lichens known to be associated with Trebouxia (for example, Ramalina spp.). The ability of some Cladonia species to associate with Trebouxia phycobionts (Osyczka et al., 2020; Shishido et al., 2021) might be helpful under such conditions (Romeike et al., 2002; de Vera, 2012; Sadowsky and Ott, 2012; Candotto-Carniel et al., 2016; Leavitt et al., 2016); however, we did not find any sample containing Trebouxia.

In a few cases, we found Asterochloris phycobionts in thalli of $S$. vesuvianum and S. canariense, even though these have high specificity towards other phycobiont genera. In some of these cases, we also found common phycobionts in the same thallus. In the case of $S$. vesuvianum, we repeatedly detected more than one Chloroidium species in a single thallus. Furthermore, we were almost unable to obtain a non-mixed sequence of phycobionts of $S$. vesuvianum at the localities on the slopes of Mt. Etna. In 
that area, Darienko et al. (2018) reported multiple free-living Chloroidium species that can coexist in Stereocaulon thalli. Paul et al. (2018) mentioned difficulties with Sanger sequencing as a possible indicator of algal plurality (i.e., the co-occurrence of multiple phycobionts in individual lichen thalli). Several authors found phycobionts with different ecological optima in a single thallus (Casano et al., 2011; Gasulla et al., 2020; Molins et al., 2020), which was also the case of multiple Chloroidium spp. in S. vesuvianum thalli. Vančurová et al. (2020) found additional algal phycobionts in Stereocaulon thalli, which were otherwise detected as the predominant phycobionts in other mycobiont species at the same locality. Therefore, we believe that phycobiont sharing is possible even in cases when the lichens differ in a predominant phycobiont. Since different lichen genera and species differ in the incidence of this phenomenon (Dal Grande et al., 2017; Smith et al., 2020), we cannot reliably estimate whether other lichen genera in the study area also show such algal plurality.

\section{Climatic Factors Driving Phycobiont Distribution}

Even though almost all phycobionts in the study area are known to be well adapted to warm areas, they spread out along the climatic gradient. We examined the differences between those phycobionts distributed in the relatively colder and more humid areas and those taking up the widest space in the middle of the climatic niche (Figure 7B). Since both mycobionts and phycobionts contribute to the ecology of the holobiont, we tested various combinations of partners.
Asterochloris mediterranea and other Asterochloris phycobionts in Stereocaulon azoreum differed significantly in 17 out of 19 tested climatic variables. However, this contrasting pair of phycobionts in thalli of $C$. rangiformis showed significant differences along four variables related to temperature. We considered the possibility that different thallus structure of lichen genera affected their water regime as suggested by Sadowsky et al. (2012); however, the pair of Chloroidium species in thalli of $S$. vesuvianum also differed somewhat in temperature-related variables. Stereocaulon azoreum was distributed only in Macaronesia, where temperature and precipitation are correlated. Hence, it is impossible to estimate what factor is crucial for driving the distribution of their phycobionts in this area. On the other hand, S. vesuvianum and C. rangiformis both grew on Sicily and the Aeolian Islands, where the climate characteristics are different. The three factors that were significant in all combinations were related to temperature, emphasizing the importance of this factor in the selection of the appropriate phycobiont. Several previous studies also found temperature to be the critical factor determining the distribution of phycobionts (Vančurová et al., 2018; Molins et al., 2020; Rolshausen et al., 2020). Rolshausen et al. (2020) recently proposed parallel symbiont turnover zones as demarcated regions where symbiont replacement is most likely to occur. In all gradients, this symbiont turnover zone is characterized by approximately $12^{\circ} \mathrm{C}$ average annual temperature. We found this pattern in all combinations, but the average annual temperature of the turnover zone was slightly higher and not uniform among the mycobiont species/



10 
genera (Figure 10). We attribute this difference to the additional influence of mycobiont selectivity. Previous studies did not determine specific turnover zones, but described the gradual change of phycobionts along the altitudinal gradient (Vargas Castillo and Beck, 2012; Gasulla et al., 2020). Moreover, Molins et al. (2020) studied Trebouxia phycobionts of Buellia zoharyi on Lanzarote, Fuerteventura, and Tenerife. They found three species that differed on their distribution ranges and the level of their tolerance to high temperatures (even under laboratory conditions). Interestingly, in corals, which is another symbiotic association similar to lichens in many aspects, the ability to cooperate with symbionts characterized by various temperature optima has been documented as an advantageous adaptive strategy (Silverstein et al., 2015). Similarly, under a scenario of global change, it may also be a critical factor for lichens (Ellis, 2019), favoring those with the ability to associate with several phycobionts covering a greater temperature gradient. However, it is possible that Cladonia, Lepraria, and Stereocaulon mycobionts or their phycobionts reached their maximum temperature limits, thus restricting their distribution ranges, because we did not find them on the warmest sites of the study area (Chazarra et al., 2011).

\section{Stereocaulon canariense as Endemic Species}

Macaronesia is known for high level of endemism (FernándezPalacios and Whittaker, 2008). As an oceanic island system, it is an attractive object for evolution studies (Emerson, 2002). Besides well-known examples of beetles and angiosperms, examples of lichen speciation have been documented within this area (Sérusiaux et al., 2011). Stereocaulon canariense was recorded only in the Canary Islands so far. However, its phycobiont, Vulcanochloris, has been rarely reported from other parts of the world as phycobiont of Stereocaulon (Kosecka et al., 2021) or other lichens (Vaiglová, 2017). The communication between Macaronesian and Mediterranean biota has been repeatedly documented (Carine et al., 2004; Vondrák et al., 2020). Consequently, other localities of this species can be found in the future. Moreover, the origin of this possibly endemic lichen can be a topic of future research.

\section{REFERENCES}

Ahmadjian, V., and Jacobs, J. B. (1981). Relationship between fungus and alga in the lichen Cladonia cristatella Tuck. Nature 289, 169-172. doi: 10.1038/289169a0

Bačkor, M., Peksa, O., Škaloud, P., and Bačkorová, M. (2010). Photobiont diversity in lichens from metal-rich substrata based on ITS rDNA sequences. Ecotoxicol. Environ. Saf. 73, 603-612. doi: 10.1016/j.ecoenv.2009.11.002

Baruffo, L., Zedda, L., Elix, J. A., and Tretiach, M. (2006). A revision of the lichen genus Lepraria s.lat. in Italy. Nova Hedwigia 83, 387-430. doi: 10.1127/0029-5035/2006/0083-0387

Beck, A. (2002). Selektivität der Symbionten schwermetalltoleranter Flechten. [dissertation thesis]. Munich, Germany: Ludwig-Maxmilians-Universität München.

Beiggi, S., and Piercey-Normore, M. D. (2007). Evolution of ITS ribosomal RNA secondary structures in fungal and algal symbionts of selected species

\section{DATA AVAILABILITY STATEMENT}

The data presented in the study are deposited in GenBank, accession numbers OL622077-OL622095 and OL625120-OL625607; and Mendeley Data: http://dx.doi.org/10.17632/428v52svtp.1.

\section{AUTHOR CONTRIBUTIONS}

LV, JM, and PŠ designed the study. LV and JM conducted the sampling and the laboratory work. JM and JS determined the samples. LV, JS, and PŠ conducted the phylogenetic and the statistical analyses. LV and JM wrote the manuscript and produced the figures with contributions from JS and PŠ. All authors contributed to the article and approved the submitted version.

\section{FUNDING}

This study was supported by Charles University Science Foundation project GAUK (grant no. 570313), Primus Research Programme of Charles University (grant no. SCI/13), and by a Long-Term Research Development grant RVO 67985939.

\section{ACKNOWLEDGMENTS}

We are grateful to J. Vančurová, J. Vondrák, L. Vančura, and K. Vančura for collecting material and/or help with field work, Z. Sejfová for help with TLC and photos, B. McCune for valuable discussions about the taxonomy of Stereocaulon, and the reviewers for their useful comments on the original version of the manuscript.

\section{SUPPLEMENTARY MATERIAL}

The Supplementary Material for this article can be found online at: https://www.frontiersin.org/articles/10.3389/fmicb.2021. 769304/full\#supplementary-material

of Cladonia sect. Cladonia. J. Mol. Evol. 64, 528-542. doi: 10.1007/ s00239-006-0115-x

Blonder, B., Lamanna, C., Violle, C., and Enquist, B. J. (2014). The n-dimensional hypervolume. Glob. Ecol. Biogeogr. 23, 595-609. doi: 10.1111/geb.12146

Boluda, C. G., Rico, V. J., Divakar, P. K., Nadyeina, O., Myllys, L., McMullin, R. T., et al. (2019). Evaluating methodologies for species delimitation: the mismatch between phenotypes and genotypes in lichenized fungi (Bryoria sect. Implexae, Parmeliaceae). Persoonia 42, 75-100. doi: 10.3767/persoonia.2019.42.04

Burgaz, A. R., and Ahti, T. (2009). Flora Liquenológica Ibérica. Vol 4. Cladoniaceae. Madrid: Sociedad Española de Liquenología.

Candotto-Carniel, F., Gerdol, M., Montagner, A., Banchi, E., De Moro, G., Manfrin, C., et al. (2016). New features of desiccation tolerance in the lichen photobiont Trebouxia gelatinosa are revealed by a transcriptomic approach. Plant Mol. Biol. 91, 319-339. doi: 10.1007/s11103-0160468-5 
Carine, M. A., Russell, S. J., Santos-Guerra, A., and Francisco-Ortega, J. (2004). Relationships of the Macaronesian and mediterranean floras: Molecular evidence for multiple colonizations into Macaronesia and back-colonization of the continent in Convolvulus (Convolvulaceae). Am. J. Bot. 91, 1070-1085. doi: 10.3732/ajb.91.7.1070

Casano, L. M., del Campo, E. M., García-Breijo, F. J., Reig-Armiñana, J., Gasulla, F., Del Hoyo, A., et al. (2011). Two Trebouxia algae with different physiological performances are ever-present in lichen thalli of Ramalina farinacea. Coexistence versus competition? Environ. Microbiol. 13, 806-818. doi: $10.1111 /$ j.1462-2920.2010.02386.x

Castresana, J. (2000). Selection of conserved blocks from multiple alignments for their use in phylogenetic analysis. Mol. Biol. Evol. 17, 540-552. doi: 10.1093/oxfordjournals.molbev.a026334

Chazarra, A., Baceló, A. M., Pires, V., Cunha, S., Silva, A., Marques, J., et al. (2011). Climate Atlas of the Archipelagos of the Canary Islands, Madeira and the Azores. Lisbon: Instituto Nacional de Meteorologia.

Crespo, A., Arguello, A., Lumbsch, H. T., Llimona, X., and Tønsberg, T. (2006). A new species of Lepraria (Lecanorales: Stereocaulaceae) from the Canary Islands and the typification of Lepraria isidiata. Lichenologist 38, 213-221. doi: 10.1017/S0024282906005846

Cubero, O. F., Crespo, A., Fatehi, J., and Bridge, P. D. (1999). DNA extraction and PCR amplification method suitable for fresh, herbarium-stored, lichenized, and other fungi. Plant Syst. Evol. 216, 243-249. doi: 10.1007/BF01084401

Dal Grande, F., Rolshausen, G., Divakar, P. K., Crespo, A., Grande, F. D., Otte, J., et al. (2017). Environment and host identity structure communities of green algal symbionts in lichens. New Phytol. 217, 277-289. doi: 10.1111/nph.14770

Darienko, T., Lukešová, A., and Pröschold, T. (2018). The polyphasic approach revealed new species of Chloroidium (Trebouxiophyceae, Chlorophyta). Phytotaxa 372, 51-66. doi: 10.11646/phytotaxa.372.1.4

Darriba, D., Taboada, G. L., Doallo, R., and Posada, D. (2012). jModelTest 2: more models, new heuristics and parallel computing. Nat. Methods 9:772. doi: $10.1038 /$ nmeth.2109

de Vera, J.-P. (2012). Lichens as survivors in space and on Mars. Fungal Ecol. 5, 472-479. doi: 10.1016/j.funeco.2012.01.008

del Arco Aguilar, M. J., and Rodríguez Delgado, O. (2018). "Vegetation of the Canary Islands" in Vegetation of the Canary Islands (Cham: Springer).

Di Gristina, E., Gottschlich, G., and Raimondo, F. M. (2016). Rediscovery of Hieracium nebrodense (Asteraceae), a little-known endemic of Sicily (Italy). Phytotaxa 265, 59-66. doi: 10.11646/phytotaxa.265.1.5

Dormann, C. F., Gruber, B., and Fruend, J. (2008). Introducing the bipartite package: analysing ecological networks. $R$ News $8,8-11$.

Ellis, C. (2019). Climate change, bioclimatic models and the risk to lichen diversity. Diversity 11:54. doi: 10.3390/d11040054

Elshobary, M. E., Osman, M. E. H., Abushady, A. M., and Piercey-Normore, M. D. (2015). Comparison of lichen-forming cyanobacterial and green algal photobionts with free-living algae. Cryptogam. Algol. 36, 81-100. doi: 10.7872/ crya.v36.iss1.2015.81

Emerson, B. C. (2002). Evolution on oceanic islands: molecular phylogenetic approaches to understanding pattern and process. Mol. Ecol. 11, 951-966.

Engelen, A., Convey, P., and Ott, S. (2010). Life history strategy of Lepraria borealis at an Antarctic inland site, coal Nunatak. Lichenologists 42, 339-346. doi: 10.1017/S0024282909990600

Fernández-Palacios, J. M., and Whittaker, R. J. (2008). The Canaries: An important biogeographical meeting place. J. Biogeogr. 35, 379-387. doi: 10.1111/j.1365-2699.2008.01890.x

Gardes, M., and Bruns, T. D. (1993). ITS primers with enhanced specificity for basidiomycetes-application to the identification of mycorrhizae and rusts. Mol. Ecol. 2, 113-118. doi: 10.1111/j.1365-294X.1993.tb00005.x

Gasulla, F., Barrasa, J. M., Casano, L. M., and del Campo, E. M. (2020). Symbiont composition of the basidiolichen Lichenomphalia meridionalis varies with altitude in the Iberian Peninsula. Lichenologists 52, 17-26. doi: 10.1017/ S002428291900046X

Giovino, A., Marino, P., Domina, G., Scialabba, A., Schicchi, R., Diliberto, G., et al. (2016). Evaluation of the DNA barcoding approach to develop a reference data-set for the threatened flora of Sicily. Plant Biosyst. 150, 631-640. doi: 10.1080/11263504.2014.989285

Guindon, S., and Gascuel, O. (2003). A simple, fast, and accurate algorithm to estimate large phylogenies by maximum likelihood. Syst. Biol. 52, 696-704. doi: $10.1080 / 10635150390235520$
Hafellner, J. (2008). Additions and corrections to the checklist and bibliography of lichens and Lichenicolous fungi of insular Laurimacaronesia. IV. Fritschiana 64, 1-28.

Hernández Padrón, C. E., and Pérez-Vargas, I. (2010). "Lichenes, lichenicolous fungi," in Lista de especies silvestres de Canarias. Hongos, plantas y animales terrestres. 2009. eds. M. Arechavaleta Hernández, S. Rodríguez Núñez, N. Zurita Pérez and A. García Ramírez (Santa Cruz de Tenerife: Gobierno de Canarias), 71-105.

Högnabba, F. (2006). Molecular phylogeny of the genus Stereocaulon (Stereocaulaceae, lichenized ascomycetes). Mycol. Res. 110, 1080-1092. doi: 10.1016/j.mycres.2006.04.013

Hutchinson, G. E. (1957). Concluding remarks. Cold Spring Harb. Symp. Quant. Biol. 22, 415-427. doi: 10.1101/SQB.1957.022.01.039

Kaasalainen, U., Tuovinen, V., Mwachala, G., Pellikka, P., and Rikkinen, J. (2021). Complex interaction networks among cyanolichens of a tropical biodiversity hotspot. Front. Microbiol. 12:672333. doi: 10.3389/fmicb.2021.672333

Kanz, B., von Brackel, W., Cezanne, R., Eichler, M., Hohmann, M.-L., Teuber, D., et al. (2015). DNA barcodes for the distinction of reindeer lichens: a case study using Cladonia rangiferina and C. stygia. Herz 28, 445-464. doi: 10.13158/heia.28.2.2015.445

Karger, D. N., Conrad, O., Böhner, J., Kawohl, T., Kreft, H., Soria-Auza, R. W., et al. (2017). Climatologies at high resolution for the earth's land surface areas. Sci. Data 4:170122. doi: 10.1038/sdata.2017.122

Katoh, K., and Standley, D. M. (2013). MAFFT multiple sequence alignment software version 7: improvements in performance and usability. Mol. Biol. Evol. 30, 772-780. doi: 10.1093/molbev/mst010

Kelly, L. J., Hollingsworth, P. M., Coppins, B. J., Ellis, C. J., Harrold, P., Tosh, J., et al. (2011). DNA barcoding of lichenized fungi demonstrates high identification success in a floristic context. New Phytol. 191, 288-300. doi: 10.1111/j.1469-8137.2011.03677.x

Kim, J. I., Kim, Y. J., Nam, S. W., So, J. E., Hong, S. G., Choi, H. G., et al. (2020). Taxonomic study of three new antarctic Asterochloris (Trebouxiophyceae) based on morphological and molecular data. Algae 35, 17-32. doi: 10.4490/ algae.2020.35.2.23

Korchikov, E. S., Bolgov, E. V., Ilyina, E. S., and Pankratov, T. A. (2018). Species diversity and photobiont localization specificities in epigene lichens (on the example of the genus Cladonia). Samara J. Sci. 7, 59-64. doi: $10.17816 /$ snv201873111

Kosecka, M., Guzow-Krzemińska, B., Černajová, I., Škaloud, P., Jabłońska, A., and Kukwa, M. (2021). New lineages of photobionts in Bolivian lichens expand our knowledge on habitat preferences and distribution of Asterochloris algae. Sci. Rep. 11:8701. doi: 10.1038/s41598-021-88110-0

Lamb, I. M. (1977). A conspectus of the lichen genus Stereocaulon (Schreb.) Hoffm. J. Hattori Bot. Lab. 43, 191-355.

Lamb, I. M. (1978). Keys to the species of the lichen genus Stereocaulon (Schreb.) Hoffm. J. Hattori Bot. Lab. 22, 209-250.

Leavitt, S. D., Kraichak, E., Nelsen, M. P., Altermann, S., Divakar, P. K., and Alors, D. (2015). Fungal specificity and selectivity for algae play a major role in determining lichen partnerships across diverse ecogeographic regions in the lichen-forming family Parmeliaceae (Ascomycota). Mol. Ecol. 24, 3779-3797. doi: 10.1111/mec.13271

Leavitt, S. D., Kraichak, E., Vondrák, J., Nelsen, M. P., Sohrabi, M., Perez-Ortega, S., et al. (2016). Cryptic diversity and symbiont interactions in rock-posy lichens. Mol. Phylogenet. Evol. 99, 261-274. doi: 10.1016/j.ympev.2016.03.030

Lindgren, H., Moncada, B., Lücking, R., Magain, N., Simon, A., Goffinet, B., et al. (2020). Cophylogenetic patterns in algal symbionts correlate with repeated symbiont switches during diversification and geographic expansion of lichen-forming fungi in the genus Sticta (Ascomycota, Peltigeraceae). Mol. Phylogenet. Evol. 150:106860. doi: 10.1016/j.ympev.2020.106860

Lücking, R. (2019). Stop the abuse of time! Strict temporal banding is not the future of rank-based classifications in fungi (including lichens) and other organisms. Crit. Rev. Plant Sci. 38, 199-253. doi: 10.1080/07352689.2019.1650517

Molins, A., Chiva, S., Calatayud, Á., Marco, F., García-Breijo, F., Reig-Armiñana, J., et al. (2020). Multidisciplinary approach to describe Trebouxia diversity within lichenized fungi Buellia zoharyi from the Canary Islands. Symbiosis 82, 19-34. doi: 10.1007/s13199-020-00722-8

Moya, P., Chiva, S., Molins, A., Jadrná, I., Škaloud, P., Peksa, O., et al. (2018). Myrmecia israeliensis as the primary symbiotic microalga in squamulose 
lichens growing in European and Canary Island terricolous communities. Fottea 18, 72-85. doi: 10.5507/fot.2017.022

Moya, P., Škaloud, P., Chiva, S., García-Breijo, F. J., Reig-Armiñana, J., Vančurová, L., et al. (2015). Molecular phylogeny and ultrastructure of the lichen microalga Asterochloris mediterranea sp. nov. from Mediterranean and Canary Islands ecosystems. Int. J. Syst. Evol. Microbiol. 65, 1838-1854. doi: 10.1099/ijs.0.000185

Muggia, L., Perez-Ortega, S., Kopun, T., Zellnig, G., and Grube, M. (2014). Photobiont selectivity leads to ecological tolerance and evolutionary divergence in a polymorphic complex of lichenized fungi. Ann. Bot. 114, 463-475. doi: $10.1093 / \mathrm{aob} / \mathrm{mcul} 46$

Nelsen, M. P., and Gargas, A. (2006). Actin type I introns offer potential for increasing phylogenetic resolution in Asterochloris (Chlorophyta: Trebouxiophyceae). Lichenologists 38, 435-440. doi: 10.1017/ S0024282906005779

Nelsen, M. P., and Gargas, A. (2008). Dissociation and horizontal transmission of codispersing lichen symbionts in the genus Lepraria (Lecanorales: Stereocaulaceae). New Phytol. 177, 264-275. doi: 10.1111/j.1469-8137.2007.02241.x

Orange, A., James, P. W., and White, F. J. (2001). Microchemical Methods for the Identification of Lichens. British Lichen Society. Available at: https:// books.google.cz/books/about/Microchemical_Methods_for_the_Identifica. html?id=IktFAQAAIAAJ\&pgis=1 (Accessed February 19, 2016).

Osyczka, P., Lenart-Boroń, A., Boroń, P., and Rola, K. (2020). Lichen-forming fungi in postindustrial habitats involve alternative photobionts. Mycologia 113, 43-55. doi: 10.1080/00275514.2020.1813486

Park, C. H., Kim, K. M., Elvebakk, A., Kim, O.-S., Jeong, G., and Hong, S. G. (2015). Algal and fungal diversity in Antarctic lichens. J. Eukaryot. Microbiol. 62, 196-205. doi: 10.1111/jeu.12159

Pateiro-Lopez, B., and Rodriguez-Casal, A. (2016). Alphahull: Generalization of the Convex Hull of a Sample of Points in the Plane. Available at: https:// cran.r-project.org/package=alphahull (Accessed June 01, 2020).

Paul, F., Otte, J., Schmitt, I., and Dal Grande, F. (2018). Comparing sanger sequencing and high-throughput metabarcoding for inferring photobiont diversity in lichens. Sci. Rep. 8:8624. doi: 10.1038/s41598-018-26947-8

Peksa, O., and Škaloud, P. (2011). Do photobionts influence the ecology of lichens? A case study of environmental preferences in symbiotic green alga Asterochloris (Trebouxiophyceae). Mol. Ecol. 20, 3936-3948. doi: 10.1111/j.1365-294X.2011.05168.x

Piercey-Normore, M. D., and DePriest, P. T. (2001). Algal switching among lichen symbioses. Am. J. Bot. 88, 1490-1498. doi: 10.2307/3558457

Pino-Bodas, R., Martín, M. P., Burgaz, A. R., and Lumbsch, H. T. (2013). Species delimitation in Cladonia (Ascomycota): a challenge to the DNA barcoding philosophy. 13, 1058-1068. Mol. Ecol. Resour. doi: 10.1111/1755-0998.12086

Pino-Bodas, R., and Stenroos, S. (2020). Global biodiversity patterns of the photobionts associated with the genus cladonia (Lecanorales, Ascomycota). Microb. Ecol. 82, 173-187. doi: 10.1007/s00248-020-01633-3

Rambold, G., Friedl, T., and Beck, A. (1998). Photobionts in lichens: possible indicators of phylogenetic relationships? Bryologist 101, 392-397. doi: 10.1639/0007-2745(1998)101[392:PILPIO]2.0.CO;2

Rolshausen, G., Hallman, U., Grande, F. D., Otte, J., Knudsen, K., and Schmitt, I. (2020). Expanding the mutualistic niche: parallel symbiont turnover along climatic gradients. Proc. R. Soc. B Biol. Sci. 287:20192311. doi: 10.1098/ rspb.2019.2311

Romeike, J., Friedl, T., Helms, G., and Ott, S. (2002). Genetic diversity of algal and fungal partners in four species of Umbilicaria (Lichenized Ascomycetes) along a transect of the Antarctic peninsula. Mol. Biol. 19, 1209-1217. doi: 10.1093/oxfordjournals.molbev.a004181

Ronquist, F., and Huelsenbeck, J. P. (2003). MrBayes 3: Bayesian phylogenetic inference under mixed models. Bioinformatics 19, 1572-1574. doi: 10.1093/ bioinformatics/btg 180

Ronquist, F., Teslenko, M., van der Mark, P., Ayres, D. L., Darling, A., Höhna, S., et al. (2012). MrBayes 3.2: efficient Bayesian phylogenetic inference and model choice Across a large model space. Syst. Biol. 61, 539-542. doi: 10.1093/sysbio/sys029

Sadowsky, A., Hussner, A., and Ott, S. (2012). Submersion tolerance in a habitat of Stereocaulon paschale (Stereocaulaceae) and Cladonia stellaris (Cladoniaceae) from the high mountain region Rondane, Norway. Nova Hedwigia 94, 323-334. doi: 10.1127/0029-5035/2012/0014

Sadowsky, A., and Ott, S. (2012). Photosynthetic symbionts in Antarctic terrestrial ecosystems: the physiological response of lichen photobionts to drought and cold. Symbiosis 58, 81-90. doi: 10.1007/s13199-012-0198-7

Sérusiaux, E., Villarreal, A. J. C., Wheeler, T., and Goffinet, B. (2011). Recent origin, active speciation and dispersal for the lichen genus Nephroma (Peltigerales) in Macaronesia. J. Biogeogr. 38, 1138-1151. doi: 10.1111/j.1365-2699.2010.02469.x

Shishido, T. K., Wahlsten, M., Laine, P., Rikkinen, J., Lundell, T., and Auvinen, P. (2021). Microbial communities of Cladonia lichens and their biosynthetic gene clusters potentially encoding natural products. Microorganisms 9:1347. doi: 10.3390/microorganisms 9071347

Silverstein, R. N., Cunning, R., and Baker, A. C. (2015). Change in algal symbiont communities after bleaching, not prior heat exposure, increases heat tolerance of reef corals. Glob. Chang. Biol. 21, 236-249. doi: 10.1111/gcb.12706

Škaloud, P., and Peksa, O. (2010). Evolutionary inferences based on ITS rDNA and actin sequences reveal extensive diversity of the common lichen alga Asterochloris. Mol. Phylogenet. Evol. 54, 36-46. doi: 10.1016/j.ympev.2009.09.035

Škaloud, P., Steinová, J., Řídká, T., Vančurová, L., and Peksa, O. (2015). Assembling the challenging puzzle of algal biodiversity: species delimitation within the genus Asterochloris (Trebouxiophyceae, Chlorophyta). J. Phycol. 51, 507-527. doi: $10.1111 /$ jpy. 12295

Smith, H. B., Dal Grande, F., Muggia, L., Keuler, R., Divakar, P. K., Grewe, F., et al. (2020). Metagenomic data reveal diverse fungal and algal communities associated with the lichen symbiosis. Symbiosis 82, 133-147. doi: 10.1007/ s13199-020-00699-4

Sparrius, L. B., Aptroot, A., Sipman, H. J. M., Pérez-Vargas, I., Matos, P., Gerlach, A., et al. (2017). Estimating the population size of the endemic lichens Anzia centrifuga (Parmeliaceae) and Ramalina species (Ramalinaceae) on Porto Santo (Madeira archipelago). Bryologist 120, 293-301. doi: 10.1639/0007-2745-120.3.293

Steinová, J., Škaloud, P., Yahr, R., Bestová, H., and Muggia, L. (2019). Reproductive and dispersal strategies shape the diversity of mycobiont-photobiont association in Cladonia lichens. Mol. Phylogenet. Evol. 134, 226-237. doi: 10.1016/j. ympev.2019.02.014

Swofford, D. L. (2003). PAUP*. Phylogenetic Analysis Using Parsimony (*and Other Methods). Sunderland, MA: Sinauer Associates.

Tretiach, M., Muggia, L., and Baruffo, L. (2009). Species delimitation in the Lepraria isidiata-L. santosii group: a population study in the MediterraneanMacaronesian region. Lichenologist 41, 1-15. doi: 10.1017/S0024282909008093

Troia, A. (2012). Insular endemism in the Mediterranean vascular flora: the case of the Aeolian Islands (Sicily, Italy). Biodivers. J. 3, 369-374.

Vaiglová, Z. (2017). Dynamics of a lichen symbiosis. [master's thesis]. Prague, Czech Republic: Charles University.

van den Boom, P. P. G., and Clerc, P. (2015). New records of lichens and lichenicolous fungi from La Gomera (Canary Islands, Spain), including the new species: Usnea boomiana P. Clerc. Candollea 70, 165-177. doi: 10.15553/c2015v702al

van den Boom, P. P. G., and Ertz, D. (2013). Further new or interesting lichens and Lichenicolous fungi of Tenerife (Canary Islands, Spain). Stapfia Rep. 99, 52-60.

van den Boom, P. P. G., and Etayo, J. (2006). New records of lichens and lichenicolous fungi from Fuerteventura (Canary Islands), with descriptions of some new species. Cryptogam. Mycol. 27, 341-374.

van den Boom, P. P. G., and Magain, N. (2020). Three new lichen species from Macaronesia belonging in Ramalinaceae, with the description of a new genus. Plant Fungal Syst. 65, 167-175. doi: 10.35535/pfsyst-2020-0011

Vančurová, L., Kalníková, V., Peksa, O., Škvorová, Z., Malíček, J., Moya, P., et al. (2020). Symbiosis between river and dry lands: Phycobiont dynamics on river gravel bars. Algal Res. 51:102062. doi: 10.1016/j.algal.2020.102062

Vančurová, L., Muggia, L., Peksa, O., Řídká, T., and Škaloud, P. (2018). The complexity of symbiotic interactions influences the ecological amplitude of the host: a case study in Stereocaulon (lichenized Ascomycota). Mol. Ecol. 27, 3016-3033. doi: 10.1111/mec.14764

Vančurová, L., Peksa, O., Němcová, Y., and Škaloud, P. (2015). Vulcanochloris (Trebouxiales, Trebouxiophyceae), a new genus of lichen photobiont from La Palma, Canary Islands, Spain. Phytotaxa 219, 118-132. doi: 10.11646/ phytotaxa.219.2.2 
Vargas Castillo, R., and Beck, A. (2012). Photobiont selectivity and specificity in Caloplaca species in a fog-induced community in the Atacama Desert, northern Chile. Fungal Biol. 116, 665-676. doi: 10.1016/j.funbio.2012.04.001

Vondrák, J., Frolov, I., Košnar, J., Arup, U., Veselská, T., Halıcı, G., et al. (2020). Substrate switches, phenotypic innovations and allopatric speciation formed taxonomic diversity within the lichen genus Blastenia. J. Syst. Evol. 58, 295-330. doi: 10.1111/jse.12503

Weber, K., and Kabsch, W. (1994). Intron positions in actin genes seem unrelated to the secondary structure of the protein. EMBO J. 13, 1280-1286. doi: 10.1002/j.1460-2075.1994.tb06380.x

White, T. J., Bruns, T., Lee, S., and Taylor, J. W. (1990). "Amplification and direct sequencing of fungal ribosomal RNA genes for phylogenetics," in PCR Protocols: A Guide to Methods and Applications. eds. M. A. Innis, D. H. Gelfand, J. J. Sninsky and T. J. White (San Diego: Academic Press), 315-322.

Yahr, R., Vilgalys, R., and Depriest, P. T. (2004). Strong fungal specificity and selectivity for algal symbionts in Florida scrub Cladonia lichens. Mol. Ecol. 13, 3367-3378. doi: 10.1111/j.1365-294X.2004.02350.x

Yahr, R., Vilgalys, R., and DePriest, P. T. (2006). Geographic variation in algal partners of Cladonia subtenuis (Cladoniaceae) highlights the dynamic nature of a lichen symbiosis. New Phytol. 171, 847-860. doi: 10.1111/j.14698137.2006.01792.x
Zwickl, D. J. (2006). Genetic Algorithm Approaches for the Phylogenetic Analysis of Large Biological Sequence Datasets under the Maximum Likelihood Criterion. Austin, TX: The University of Texas at Austin.

Conflict of Interest: The authors declare that the research was conducted in the absence of any commercial or financial relationships that could be construed as a potential conflict of interest.

Publisher's Note: All claims expressed in this article are solely those of the authors and do not necessarily represent those of their affiliated organizations, or those of the publisher, the editors and the reviewers. Any product that may be evaluated in this article, or claim that may be made by its manufacturer, is not guaranteed or endorsed by the publisher.

Copyright (C) 2021 Vančurová, Malíček, Steinová and Škaloud. This is an open-access article distributed under the terms of the Creative Commons Attribution License (CC BY). The use, distribution or reproduction in other forums is permitted, provided the original author(s) and the copyright owner(s) are credited and that the original publication in this journal is cited, in accordance with accepted academic practice. No use, distribution or reproduction is permitted which does not comply with these terms. 